Article

\title{
Synthesis and Features of Luminescent Bromo- and Iodohectorite Nanoclay Materials
}

\author{
Hellen Silva Santos ${ }^{1,2}, *$, Isabella Norrbo ${ }^{1,2}$ (i), Tero Laihinen ${ }^{1}$, Jari Sinkkonen ${ }^{1}$, \\ Ermei Mäkilä ${ }^{2,3}$, José M. Carvalho ${ }^{4}$, Pia Damlin ${ }^{1,5}$, Hermi F. Brito ${ }^{6}$, Jorma Hölsä ${ }^{7}$ \\ and Mika Lastusaari ${ }^{1,5}$ \\ 1 Department of Chemistry, University of Turku, FI-20014 Turku, Finland; tijnor@utu.fi (I.N.); \\ tero.laihinen@utu.fi (T.L.); jari.sinkkonen@utu.fi (J.S.); pia.damlin@utu.fi (P.D.); mika.lastusaari@utu.fi (M.L.) \\ 2 Doctoral Programme in Physical and Chemical Sciences, University of Turku Graduate School (UTUGS), \\ FI-20014 Turku, Finland; ermei.makila@utu.fi \\ 3 Department of Physics and Astronomy, University of Turku, FI-20014 Turku, Finland \\ 4 Department of Applied Physics, Institute of Physics, University of São Paulo, São Paulo BR-05508090, Brazil; \\ jmc@iq.usp.br \\ 5 Turku University Centre for Materials and Surfaces (MatSurf), FI-20014 Turku, Finland \\ 6 Department of Fundamental Chemistry, Institute of Chemistry, University of São Paulo, \\ São Paulo BR-05508000, Brazil; hefbrito@iq.usp.br \\ 7 Department of Physics, University of the Free State, Bloemfontein ZA-9300, South Africa; jorma.holsa@utu.fi \\ * Correspondence: hellen.santos@utu.fi; Tel.: +358-29-450-3202
}

Received: 1 November 2017; Accepted: 27 November 2017; Published: 30 November 2017

\begin{abstract}
The smectites represent a versatile class of clay minerals with broad usage in industrial applications, e.g., cosmetics, drug delivery, bioimaging, etc. Synthetic hectorite $\mathrm{Na}_{0.7}\left(\mathrm{Mg}_{5.5} \mathrm{Li}_{0.3}\right)\left[\mathrm{Si}_{8} \mathrm{O}_{20}\right](\mathrm{OH})_{4}$ is a distinct material from this class due to its low-cost production method that allows to design its structure to match better the applications. In the current work, we have synthesized for the first time ever nanoclay materials based on the hectorite structure but with the hydroxyl groups $\left(\mathrm{OH}^{-}\right)$replaced by $\mathrm{Br}^{-}$or I ${ }^{-}$, yielding bromohectorite $(\mathrm{Br}-\mathrm{Hec})$ and iodohectorite (I-Hec). It was aimed that these materials would be used as phosphors. Thus, $\mathrm{OH}^{-}$ replacement was done to avoid luminescence quenching by multiphonon de-excitation. The crystal structure is similar to nanocrystalline fluorohectorite, having the $d_{001}$ spacing of $14.30 \AA$ and $3 \mathrm{~nm}$ crystallite size along the 001 direction. The synthetic materials studied here show strong potential to act as host lattices for optically active species, possessing mesoporous structure with high specific surface area (385 and $363 \mathrm{~m}^{2} \mathrm{~g}^{-1}$ for Br-Hec and I-Hec, respectively) and good thermal stability up to $800{ }^{\circ} \mathrm{C}$. Both materials also present strong blue-green emission under UV radiation and short persistent luminescence (ca. $5 \mathrm{~s}$ ). The luminescence features are attributed to $\mathrm{Ti}^{3+} / \mathrm{Ti}^{\mathrm{IV}}$ impurities acting as the emitting center in these materials.
\end{abstract}

Keywords: bromohectorite; iodohectorite; clay materials; host lattice; titanium luminescence

\section{Introduction}

Clay minerals have been known since antiquity, when their applications were first explored to obtain products ranging from ceramics to health-related materials [1,2]. Nowadays, these materials play important role in the research of diversified fields such as solar cell production $[3,4]$, environmentally friendly heterogeneous catalysts [5,6], photo-catalysts [7], coatings [8,9], cosmetics products [10] and biomedical applications (e.g., drug delivery, bioimaging, tissue engineering, regenerative medicine) [1]. This wide variety of applications is due to their convenient physicochemical features such as plasticity, 
swelling capacity, anisotropy of the layers, ion-exchange properties as well as the associated low cost of production $[1,2,11]$.

Clay minerals are composed of two types of polymeric sheets. One type has tetrahedral $(\mathrm{T})$ units as building blocks, and the second is formed from octahedral $(\mathrm{O})$ units. The different types of clay minerals are classified into two groups based on the way these sheets connect to each other, i.e., T:O and T:O:T. The T:O type of clay minerals have rigid structures with the layers sequentially stacked to each other with a very small space between them. These types of clay minerals are thus used, e.g., as scaffolds for the production of ceramic materials [2], immobilization of proteins [12] and generation of nano-inorganic micelles to capture hydrocarbon and aromatic oils in vapor and liquid states [13].

On the other hand, T:O:T type materials have a much more flexible structure because the layers are connected to each other through a large interlayer space filled with hydrated cations in order to compensate for the negative charges originating from the aliovalent substitutions. Such negatively charged layers are regarded as one of the most important characteristics of the T:O:T type clay minerals due to the easy cation exchange and high absorption potential of the interlayer space. In fact, it is in the interlayer space where the most important technological functionalities of the T:O:T type clay minerals originate [2]. Different types of T:O:T materials have been employed in a broad range of applications. For instance, many smectite clays have been used for producing bionanocomposites for scaffolds and regenerative medicine [14]. Mechanochemically activated saponite can be used for the selective removal of $\mathrm{Cu}^{2+}$ and $\mathrm{Ni}^{2+}$ from aqueous solutions [15]. Fluorohectorite clay has proven to be an effective material for drug delivery of ciprofloxacin with a controlled release rate [16], and hectorite has been used to improve the abrasion resistance, water vapor barrier and anticorrosion properties of nanocomposite coatings [17].

Among this large group of T:O:T type clay minerals, the smectites represent the largest and most important class [11] because of their distinguished features such as high specific surface area, easily tunable structure, moderate layer charge and propensity for intercalating extraneous species of variable sizes [2]. Moreover, the ability of intercalating additional activator species into the interlayer space of smectites can produce a variety of optically active materials [18]. Although natural smectites can be found in abundance, they usually contain high concentrations of impurities (e.g., quartz, $\mathrm{K}, \mathrm{Na}, \mathrm{Ca}$, $\mathrm{Mg}, \mathrm{Fe}$, and diverse organic impurities, depending on the sedimentation characteristic of the extracting mine) and structural defectAs (e.g., cis- or trans-vacancies, orientation of tetrahedra, localization of isomorphous substitutions, and stacking faults) [11,19], which may deteriorate the performance of luminescent materials. Therefore, the current work is focused on the study of synthetic hectorite-like types of smectites, aiming for their application as host matrices for optically active species.

Synthetic hectorite $\mathrm{Na}_{0.7}\left(\mathrm{Mg}_{5.5} \mathrm{Li}_{0.3}\right)\left[\mathrm{Si}_{8} \mathrm{O}_{20}\right](\mathrm{OH})_{4}$ is easily obtained at low temperatures and pressures $[11,20]$, which enables its production in high quantities, at low prices and with controllable composition, purity and crystal dimensions [1]. Hectorite is a T:O:T (or 2:1) type of trioctahedral smectite, meaning it is composed of two sheets of corner-sharing $\mathrm{SiO}_{4}$ tetrahedra $(\mathrm{T})$ intercalated with one sheet of edge-sharing $\mathrm{M}(\mathrm{O}, \mathrm{OH})_{6}$ octahedra $(\mathrm{O})$, where $\mathrm{M}$ is $\mathrm{Mg}^{2+}$ or $\mathrm{Li}^{+}$. These $\mathrm{T}: \mathrm{O}: \mathrm{T}$ units are negatively charged, and they are electrostatically connected to each other across the interlayer space composed of hydrated $\mathrm{Na}^{+}$species [2,11]. This composition may vary, for instance when $\mathrm{OH}^{-}$ groups are partially replaced by $\mathrm{F}^{-}$, creating fluorohectorite $[11,21]$. When aiming for luminescence applications, the $\mathrm{OH}^{-}$groups of the hectorite structure must be avoided since the high energy phonons of these ions $\left(3500 \mathrm{~cm}^{-1}\right)$ can cause luminescence quenching through multiphonon de-excitation [22].

The primary goals of the current work were to design and synthesize bromohectorite $(\mathrm{Br}-\mathrm{Hec})$ and iodohectorite (I-Hec) nanoclay materials based on the hectorite structure, but with the hydroxyl groups replaced by $\mathrm{Br}^{-}$and $\mathrm{I}^{-}$. The second intention was to maintain the essential features characteristic of hectorites that are needed for future applications, i.e., high surface area and good thermal stability. Finally, it was intended that the materials would show the inherent broadband luminescence emission observed earlier for fluoro- [23] and chlorohectorite [24]. To the best of the authors' knowledge, 
the synthesis and properties of bromohectorite and iodohectorite are now being reported for the first time.

\section{Materials and Methods}

\subsection{Synthesis}

The Br-Hec and I-Hec $\mathrm{Na}_{0.7}\left(\mathrm{Mg}_{5.5} \mathrm{Li}_{0.3}\right)\left[\mathrm{Si}_{8} \mathrm{O}_{20}\right](\mathrm{X})_{4}, \mathrm{X}=\mathrm{Br}$, I) were synthesized using a hydrothermal crystallization method [20] in a reflux system at $100{ }^{\circ} \mathrm{C}$. The $\mathrm{Br}-\mathrm{Hec}$ was made by preparing a colloidal mixture with stoichiometric amounts of $\operatorname{LiBr}(\geq 99 \%$, Sigma-Aldrich, St. Louis, MO, USA), MgO ( $\geq 97 \%$, Merck, Darmstadt, Germany), $\mathrm{SiO}_{2}$ (99.8\%, Sigma-Aldrich, St. Louis, MO, USA) and a threefold excess of $\mathrm{NaBr}(\geq 99 \%$, J.T. Baker, Center Valley, PA, USA) in a neutral aqueous solution, keeping the mixture in a reflux system for $24 \mathrm{~h}$. I-Hec was otherwise synthesized similarly but with LiBr replaced by LiI ( $\geq 99.9 \%$, Fluka, Buchs, Switzerland) and $\mathrm{NaBr}$ replaced by NaI ( $\geq 99.5 \%$, Merck, Darmstadt, Germany). After ceasing the reflux, both materials were vacuum filtered and washed with deionized water six consecutive times to remove the excess halogen ions from the filtrate liquids, which were checked with the silver nitrate test. Thereafter, both materials were dried for $12 \mathrm{~h}$ at $200^{\circ} \mathrm{C}$.

The X-Hec materials were doped with $\mathrm{Ti}^{3+}$ in three steps, through a cation exchange reaction described previously [24]. First, homogeneous colloidal suspensions were generated by adding $0.1 \mathrm{~g}$ of neutral X-Hec into $10 \mathrm{~cm}^{3}$ of deionized water, while continuously stirring and heating $(30 \mathrm{~min}$ at $50{ }^{\circ} \mathrm{C}$ ). Then, stoichiometric amounts of a $0.1 \mathrm{~mol} \mathrm{dm}{ }^{-3}$ aqueous solution of $\mathrm{TiCl}_{3}$ (about $15 \%$ of $\mathrm{TiCl}_{3}$ in about $10 \%$ of hydrochloric acid, Merck, Darmstadt, Germany) were added to these suspensions to obtain $0.1 \mathrm{~mol} \%$ of $\mathrm{Ti}^{3+}$ (relative to the $\mathrm{Na}^{+}$amount in the interlayer space). The suspensions were stirred and heated $\left(3 \mathrm{~h}\right.$ at $\left.200{ }^{\circ} \mathrm{C}\right)$ and then vacuum filtered and dried $\left(12 \mathrm{~h}\right.$ at $\left.200^{\circ} \mathrm{C}\right)$.

\subsection{Characterization}

The crystal structure and purity of the Br-Hec and I-Hec were investigated by X-ray powder diffraction (XPD) measurements at room temperature (RT) with a Huber G670 Guinier camera (Huber, Rimsting, Germany), using an image plate detector and $\mathrm{Cu} \mathrm{K}_{\alpha 1}$ radiation. The crystallite size was calculated with the Scherrer formula [23-25].

The chemical bonds formed at the molecular level of both nanoclays were studied with FTIR measurements. The spectra were determined at RT in the range of $400-4000 \mathrm{~cm}^{-1}$ using a Bruker Vertex 70 spectrometer (Bruker Optics Scandinavia AB, Solna, Sweden) equipped with a RT-DLaTGS detector and a VideoMVP ${ }^{\mathrm{TM}}$ Diamond ATR accessory. For each spectrum, a total of 320 interferograms were co-added using $4 \mathrm{~cm}^{-1}$ as resolution. For the diamond as internal reflection element in the attenuated total reflection (ATR) method, the limitation is as follows: intrinsic absorption from approximately 2300 to $1800 \mathrm{~cm}^{-1}$ limits its usefulness in this region (gives in this range only $5 \%$ transmission).

The qualitative compositions of the Br- and I-Hec were analysed through X-ray fluorescence spectroscopy (XRF) with a Panalytical Epsilon 1 apparatus (Panalytical, Almelo, The Netherlands), using $\mathrm{Ag} \mathrm{K}_{\alpha}$ radiation $(22.16 \mathrm{keV}$ ), and a high-resolution $\mathrm{Si}$ drift detector (with a typical energy resolution of $135 \mathrm{eV}$ at $5.9 \mathrm{keV} / 1000 \mathrm{cps}$ ).

The chemical environment around the $\mathrm{Si}^{\mathrm{IV}}$ cations of the $\mathrm{Br}-\mathrm{Hec}$ and $\mathrm{I}-\mathrm{Hec}$ was studied with solid-state ${ }^{29} \mathrm{Si}$ MAS NMR spectroscopy. The spectra were recorded for $24 \mathrm{~h}$ at room temperature with a Bruker AV400 spectrometer (Bruker, Fällanden, Switzerland) using a 10,000 Hz spinning rate and a $60 \mathrm{~s}$ relaxation time. The parts per million scale was calibrated against tetramethylsilane (TMS) at $0.00 \mathrm{ppm}$, designated by the equipment.

The surface area and porosity of both nanoclays were determined by nitrogen sorption at $77 \mathrm{~K}$, measured through a TriStar 3000 apparatus (Micromeritics, Norcross, GA, USA). The surface area was calculated with the Brunauer-Emmett-Teller (BET) method [26]. The volume of the mesopores was estimated using the total adsorbed amount at a relative pressure $p / p^{0}=0.97$ [27]. 
The thermal stability of the Br-Hec and I-Hec was studied with a TA Instruments SDT Q600 simultaneous TGA-DSC apparatus (TA Instruments, New Castle, DE, USA). Approximately $20 \mathrm{mg}$ of each material was heated from 25 to $1000{ }^{\circ} \mathrm{C}$ in flowing $\mathrm{N}_{2}$ (rate flow: $100 \mathrm{~cm}^{3} \mathrm{~min}^{-1}$, heating rate: $\left.10{ }^{\circ} \mathrm{C} \mathrm{min}^{-1}\right)$. An empty aluminum oxide crucible was used as the reference material, and similar crucibles were used as sample pans.

The visual appearance of both materials was recorded with photos taken with a Canon EOS $60 \mathrm{D}$ camera (Canon, Tokyo, Japan), which has 18 megapixel resolution and $5.3 \mathrm{fps}$ shooting speed. The emission and excitation spectra as well as luminescence decay curves were measured at RT with an Agilent Varian Cary Eclipse spectrophotometer (Agilent, Santa Clara, CA, USA), using a 150 W Xe lamp as the excitation source.

\section{Results}

\subsection{Structural Characterization and Purity}

The XPD patterns of the bromohectorite and iodohectorite (Figure 1) show that both materials have a hexagonal crystal structure similar to nanocrystalline fluorohectorite, indicating that no crystalline impurities were detected within the detection limit of the equipment. The $\mathrm{Br}-\mathrm{Hec}$ and I-Hec have a $\mathrm{d}_{001}$ spacing of $14.30 \AA$ (equivalent to $6.2^{\circ}$ in $2 \theta$ ), indicating two hydrate layers in their interlayers when recorded at room temperature [28]. The spacing falls in the middle of the range of 10-20 predicted for the basal spacing of smectites [29]. Due to the nanosize of the crystallites, the respective reflections are regularly broad, generating an extensive overlap that does not allow for an accurate determination of their FWHMs. However, the single (001) reflection at $6.2^{\circ}$ (in 20) is suitable for carrying out the Scherrer calculations [25] to determine the diffracting domain size, which indicates the size of approximately $3 \mathrm{~nm}$ along the 001 direction for both materials. The XPD patterns of the materials also indicate the formation of a plate-like morphology, because the (001) reflections are wider than the others, which means that the crystallites are larger in the other directions, i.e., the (h00) and (0k0) directions.

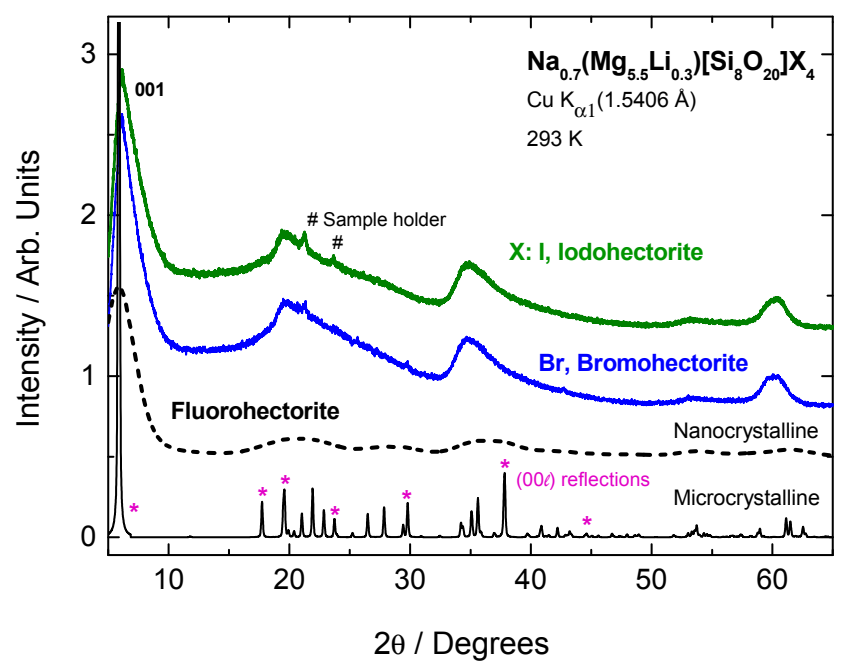

Figure 1. The XPD patterns of the bromohectorite and iodohectorite. The reference patterns for nanoand microcrystalline fluorohectorite were calculated with PowderCell v 2.4 program (W. Kraus and G. Nolze, BAM, Berlin, Germany, 2000) using structural data from [30].

The XRF spectra of Br-Hec and I-Hec (Figure 2) confirmed the expected chemical composition of the materials. Both spectra show the lines related to the $\mathrm{Mg} \mathrm{K}_{\alpha 1}$, Si $\mathrm{K}_{\alpha 1}$, and $\mathrm{Ca} \mathrm{K}_{\alpha 2}$ emissions at 1.25, 1.74 , and $3.69 \mathrm{keV}$, respectively [31]. Here the presence of calcium may be associated to its common presence as impurity in the sodium halide precursors used in the synthesis. Therefore, it is expected 
that the calcium cations share the interlayer space of the nanoclay materials together with the $\mathrm{Na}^{+}$ions. Also, the spectra show the lines of $\mathrm{Ag}_{\mathrm{L}}, \mathrm{L}_{\alpha 1,2}, \mathrm{~L}_{\beta 1}, \mathrm{~L}_{\beta 2}$ and $\mathrm{L}_{\gamma 1}$, from 2.63 to $3.52 \mathrm{keV}$ [31], which are due to the silver excitation source of the equipment. The XRF spectrum of the Br-Hec exhibits the line of $\mathrm{Br} \mathrm{L} \mathrm{L}_{\alpha 1,2}$ emission at $1.48 \mathrm{keV}$, confirming the presence of bromine. Similarly, the iodine in the composition of the I-Hec is observed as the emission lines of $\mathrm{I}_{\alpha 1}, \mathrm{~L}_{\beta 1}$ and $\mathrm{L}_{\beta 2}$ at 3.94, 4.22 and $4.51 \mathrm{keV}$, respectively. Moreover, the spectra of both materials indicate the presence of Ti as an impurity witnessed by the weak $\mathrm{K}_{\beta 1}$ line at $4.9 \mathrm{keV}$.
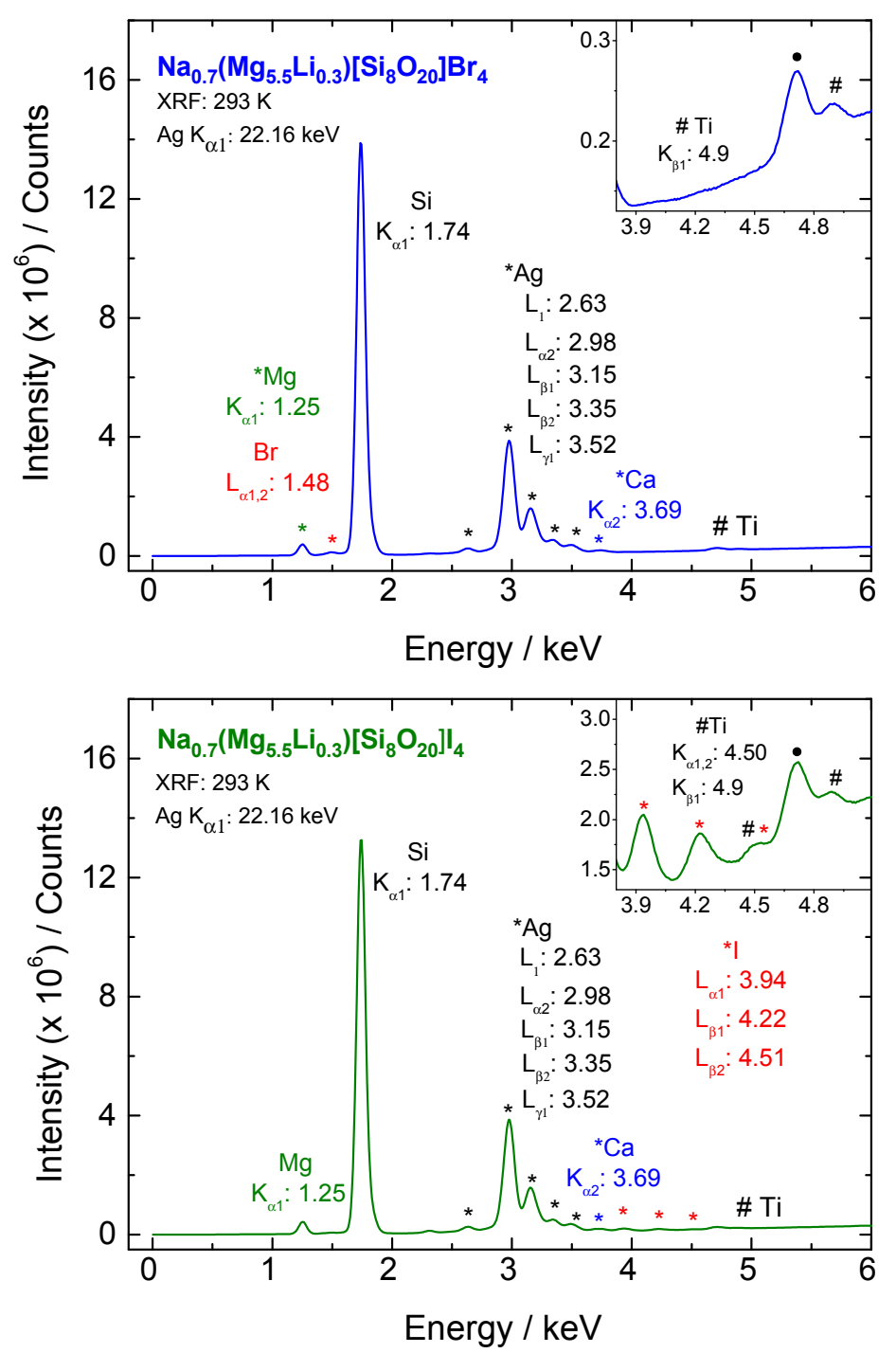

Figure 2. The XRF spectra of bromohectorite (top) and iodohectorite (bottom). The upper insertions show the presence of Ti impurities in both materials (•: instrumental signal).

The FTIR spectra of Br-Hec and I-Hec (Figure 3) show a strong band at $460 \mathrm{~cm}^{-1}$ related to the symmetric stretching of $\mathrm{Mg}-\mathrm{O}$ in the octahedral units of hectorite type clay minerals [32]. In addition, both spectra present the $\mathrm{Si}-\mathrm{O}-\mathrm{Si}$ bands of the tetrahedral layers of ordered hectorite at 660,800 , and $1010-1090 \mathrm{~cm}^{-1}$ related to the bending as well as symmetric and asymmetric stretching modes of $\mathrm{Si}-\mathrm{O}-\mathrm{Si}$, respectively [32,33]. None of the synthesized materials show indication of an amorphous silica phase that would be observed as a weak band at $1200 \mathrm{~cm}^{-1}$ [33]. The weak bands at ca. 1625 and $3300 \mathrm{~cm}^{-1}$ are assigned to the $\mathrm{H}-\mathrm{O}-\mathrm{H}$ bending and stretching, respectively, indicating low amounts of adsorbed water on the clays and/or water present in the hydration shell of the $\mathrm{Na}^{+}$cations in the 
interlayer space of both clay materials [34]. Moreover, in the FTIR spectra of Br-Hec or I-Hec there are no bands related to the vibration of hydroxyl groups in the octahedral layers of clay minerals. In common hectorite clays these are observed as strong sharp bands in the region from 3600 to $3700 \mathrm{~cm}^{-1}$ [32,34]. Therefore, the absence of these hydroxyl bands indicates that both materials, Br-Hec and I-Hec, have their octahedral units formed with the respective halogens, instead of the common $\mathrm{OH}^{-}$groups of hectorite.

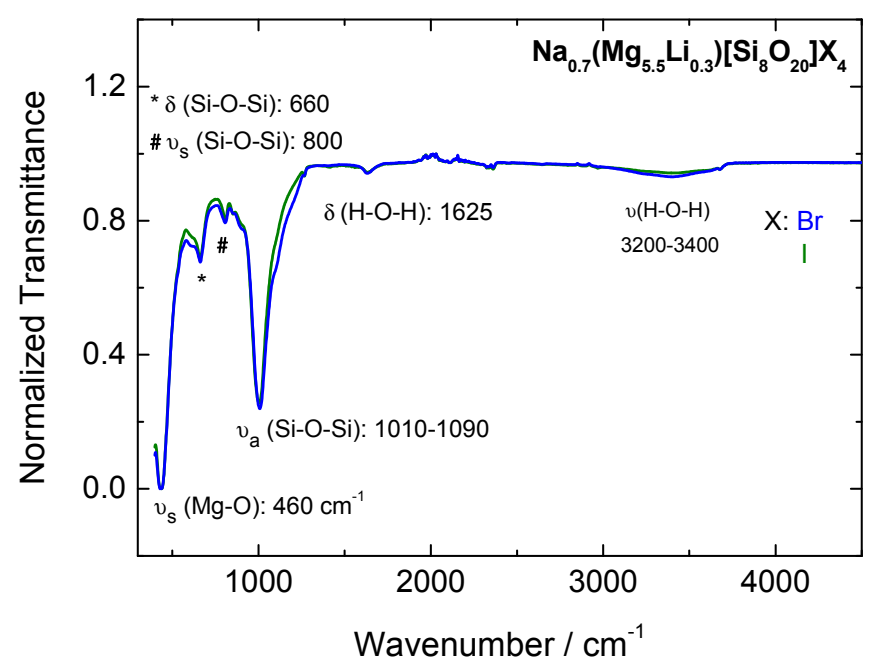

Figure 3. The FTIR spectra of the bromohectorite and iodohectorite.

The ${ }^{29} \mathrm{Si} \mathrm{NMR}$ spectra of Br-Hec and I-Hec (Figure 4) indicate that the fractions of silicon present in the tetrahedral sheets have the same chemical environment that is predicted for the tetrahedral layers of synthetic hectorite. The most intense resonance signals at -98 ( $\mathrm{Br}-\mathrm{Hec})$ and $-96 \mathrm{ppm}$ (I-Hec) are related to the $\mathrm{Q}^{3}$ sites of the $\mathrm{Si}(\mathrm{OMg})(\mathrm{OSi})_{3}$ type, as anticipated for the hectorite framework $[35,36]$. The signal observed for both clays at ca. $-87 \mathrm{ppm}$ is associated with the $\mathrm{Q}^{2}$ chemical shift of $\mathrm{SiO}_{4}$ tetrahedra linked to other two tetrahedral units by oxygen bonds [37], which in the $\mathrm{Br}-\mathrm{Hec}$ and I-Hec structures may be represented by $\mathrm{Si}(\mathrm{OMg})(\mathrm{OSi})_{2} \mathrm{X}\left(\mathrm{X}=\mathrm{Br}^{-}\right.$or $\left.\mathrm{I}^{-}\right)$groups, having the halogens at the apical (trans) positions in the octahedral layers [35]. Additionally to the expected previous signals, both materials also present a weaker signal at ca. $-111 \mathrm{ppm}$ indicating the presence of $\mathrm{Q}^{4}$ $\mathrm{Si}(\mathrm{OSi})_{4}$ centers, which may be due to small amounts of an amorphous silica framework (amorphous silica) $[35,37]$.

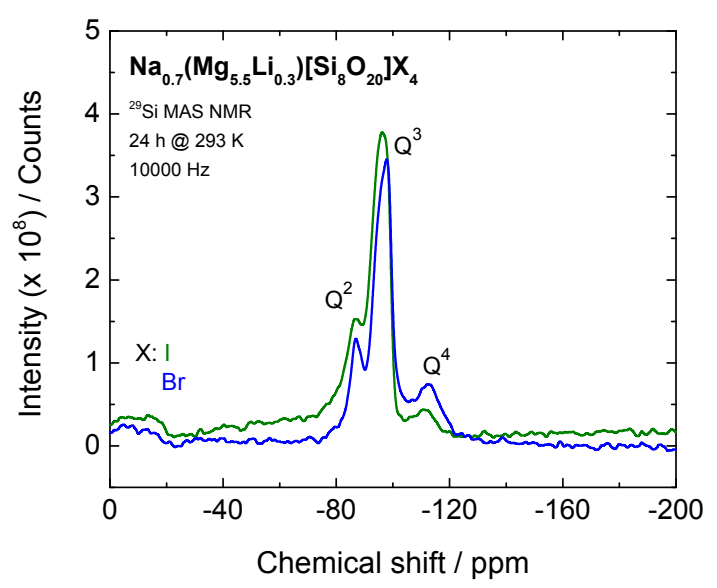

Figure 4. The ${ }^{29}$ Si MAS NMR spectra of bromohectorite and iodohectorite clay materials. 
The degree of branching relative to the chain (of the tetrahedral layers) was estimated by the ratio between the intensities of the $\mathrm{Q}^{2}$ and $\mathrm{Q}^{3}$ signals $\left(\mathrm{Q}^{2} / \mathrm{Q}^{3}\right)$ [37]. The calculated ratios were 0.37 and 0.41 for the $\mathrm{Br}-\mathrm{Hec}$ and I-Hec, respectively, which indicates a higher degree of branching for the polymeric sheets for I-Hec than Br-Hec.

\subsection{Porosity, Packing, and Thermal Stability}

The porosity and packing properties of $\mathrm{Br}-\mathrm{Hec}$ and $\mathrm{I}-\mathrm{Hec}$ were evaluated through nitrogen sorption isotherms, recorded in triplicate at $77 \mathrm{~K}$ for both materials (Figure 5). Both materials display adsorption isotherms with the shape typical of type $\mathrm{V}$, according to the IUPAC classification [38], which is characteristic of mesoporous materials. Since $\mathrm{Br}-\mathrm{Hec}$ and $\mathrm{I}-\mathrm{Hec}$ behave as mesoporous materials, the hysteresis loop of their sorption isotherms can be correlated with their texture. The sorption isotherms of both clay materials show the $\mathrm{H}_{3}$ hysteresis loop, according to the IUPAC classification [38]. Such a type of hysteresis loop points out that these mesoporous materials have slit-shaped pores, which indicates that there are no limitations for adsorption at high $\mathrm{p} / \mathrm{p}_{0}$. This is a typical feature of non-rigid aggregates of plate-like particles [38]. This plate-like structure was also evident in the XPD patterns (discussed above), and is confirmed with the respective $\mathrm{N}_{2}$ sorption isotherms.

The physisorption phenomena were analysed using two data reduction methods, in order to calculate the surface area and the pore volume of each material (Figure 5). The surface areas were calculated using the BET method [26], considering the model of a multilayer coverage. The Br-Hec has a surface area of $385 \mathrm{~m}^{2} \mathrm{~g}^{-1}$, while the I-Hec gives the area of $363 \mathrm{~m}^{2} \mathrm{~g}^{-1}$, which are higher than those described in the literature for synthetic hectorites (5 to $\left.300 \mathrm{~m}^{2} \mathrm{~g}^{-1}\right)$ [39], but similar to those reported for Laponite ${ }^{\circledR}$ (between 279 and $375 \mathrm{~m}^{2} \mathrm{~g}^{-1}$ ) [39,40].

The volume of the mesopores was calculated using the method described by Rouquerol et al. [27], indicating the value of 0.48 and $0.50 \mathrm{~cm}^{3} \mathrm{~g}^{-1}$ for the $\mathrm{Br}-\mathrm{Hec}$ and I-Hec, respectively. The pore volumes of the materials did not change from the adsorption to the desorption curve. Thus, these materials have the reversible adsorption process expected for mesoporous materials and needed for catalysts.

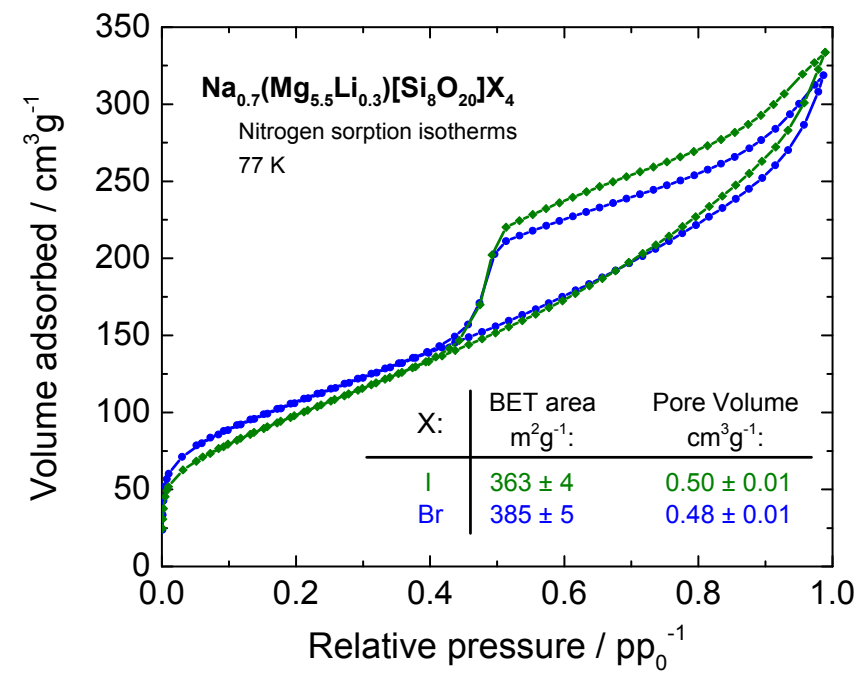

Figure 5. The nitrogen sorption isotherms of bromohectorite and iodohectorite.

The TGA-DSC curves of Br-Hec and I-Hec (Figure 6) show that the mineral structure is stable up to $800{ }^{\circ} \mathrm{C}$. The materials show the three main events expected for hectorite type of clay minerals. The first asymmetric endothermic signal is related to the loss of adsorbed water molecules $[35,41]$. This is observed in the DSC curves as a single event at $89^{\circ} \mathrm{C}$ for the $\mathrm{Br}-\mathrm{Hec}$ and at $114{ }^{\circ} \mathrm{C}$ for the I-Hec. The temperature ranges related to these occurrences are better observed in the first derivatives of the 
TGA curves (Figure A1), which indicate that these first events are accompanied with mass losses of $3 \%$ $\left(30-135^{\circ} \mathrm{C}\right)$ and $1.8 \%\left(30-191{ }^{\circ} \mathrm{C}\right)$ for Br-Hec and I-Hec, respectively.

The second event represents the loss of the coordinated water from the interlayer space of the smectites (in the inner hydration shell of $\mathrm{Na}^{+}$) and locked water inside possible voids in the clays' structure $[35,41]$. Although the TGA and DSC curves do not show this event clearly, it can be well identified from the first derivatives (Figure A1). This loss of coordinated water involves a mass loss of $7.2 \%$ and $6.5 \%$ for $\mathrm{Br}-\mathrm{Hec}$ and I-Hec, respectively. The total water losses were $10.2 \%$ and $8.3 \%$ for $\mathrm{Br}-\mathrm{Hec}$ and I-Hec, respectively, which is consistent with the higher surface area observed for Br-Hec.

The strong exothermic signal in the DSC curves shows the collapse of the mineral structure (Figure 6). This was observed at 828 and $813^{\circ} \mathrm{C}$ for the Br-Hec and I-Hec, respectively, showing a mass loss of ca. $2.5 \%$ for both materials. The total mass losses (from 30 to $1000{ }^{\circ} \mathrm{C}$ ) were $12.7 \%$ and $10.8 \%$ for the bromo and iodo-hectorites, respectively. The collapse results mainly in the formation of two other minerals: enstatite $\left(\mathrm{MgSiO}_{3}\right)$ and cristobalite $\left(\mathrm{SiO}_{2}\right)$, which was confirmed by XPD measurements of the decomposed materials after the thermal analysis, where the materials were heated up to $1000{ }^{\circ} \mathrm{C}$ (Figure A2). Because the XRF data showed a similar $\mathrm{Br}$ and I content in the materials before and after heating to $1000{ }^{\circ} \mathrm{C}$ (Figure A3), it may be that magnesium bromide or iodide is also present. However, it is difficult to confirm this from the XPD patterns, because of the broad features of the reflections between $26^{\circ}$ and $32^{\circ}$, where the most intense reflections of $\mathrm{MgBr}_{2}$ or $\mathrm{MgI}_{2}$ should be observed (Figure A2). The formation of lithium oxide, sodium oxide, and other crystalline phases with the respective halogens are also possible. They were not identified in the XPD analysis, but this may be due to the overlapping of reflections in the diffractograms or the low crystallinity of those species.

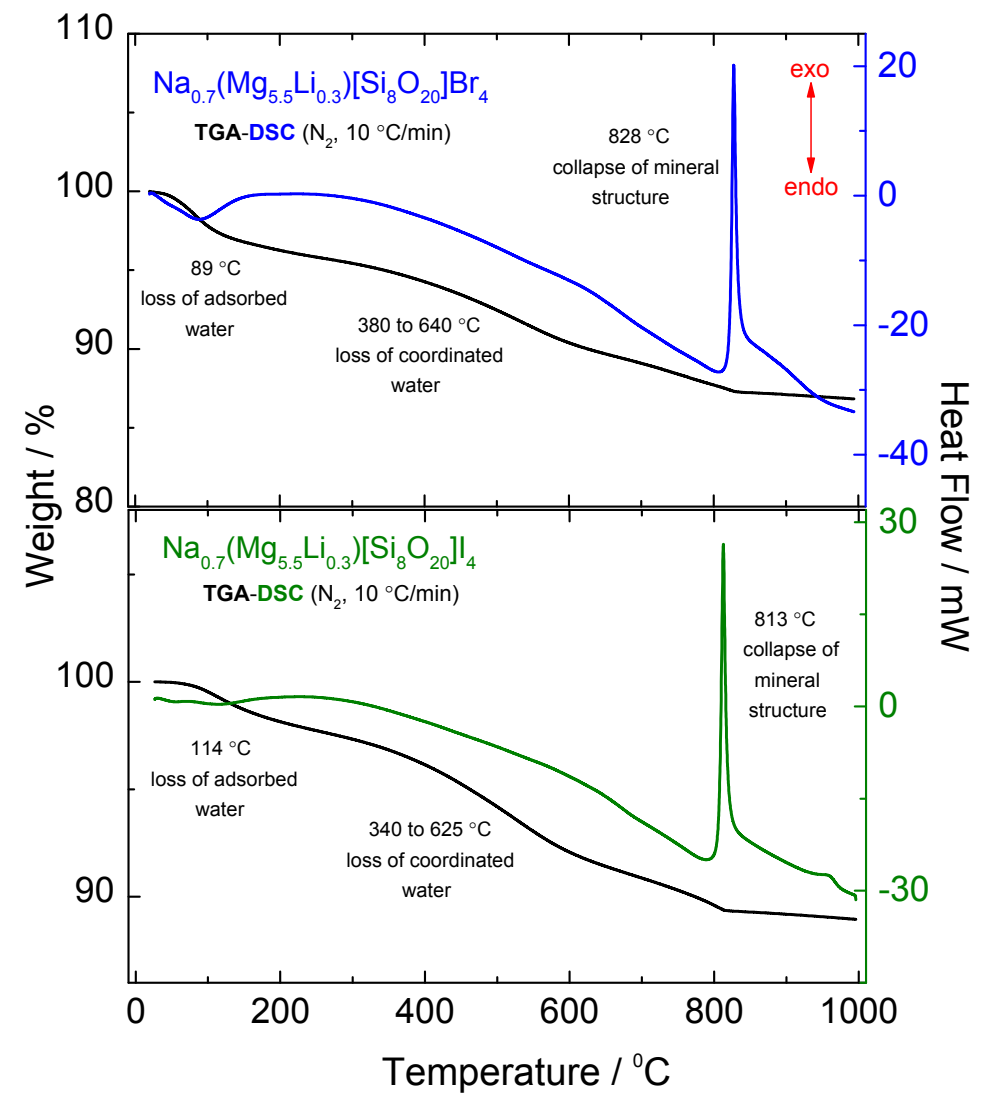

Figure 6. The heating TGA-DSC curves of the bromohectorite (top) and iodohectorite (bottom). 


\subsection{Luminescence Properties}

The Br-Hec and I-Hec materials display a yellowish body color under white light; however, when the materials are exposed to UV radiation, they show blue emission (Figure 7). The emission spectra $\left(\lambda_{\text {exc }}: 255 \mathrm{~nm}\right.$ ) show a main broad blue-green emission band for both materials (Figure 7 , upper). This main emission is centered at $470 \mathrm{~nm}$ for the $\mathrm{Br}-\mathrm{Hec}$ material, while the I-Hec material has the center of the band red shifted to $490 \mathrm{~nm}$. Additionally, both materials have a weak red emission at ca. $710 \mathrm{~nm}$, which is more prominent for Br-Hec but probably overlapping with the main emission for the I-Hec material, where it is seen as a weak shoulder. When the materials are excited at $365 \mathrm{~nm}$, their main emission band appears as a broad green-yellow emission (Figure 7, lower), having its barycenter at ca. 530 and $562 \mathrm{~nm}$ for Br-Hec and I-Hec, respectively, while the weak red emission remains at ca. $710 \mathrm{~nm}$. When the materials are excited at different wavelengths, there is a tendency that the main emission band is shifted towards red with increasing excitation wavelength (Figures A4 and A5). This change in the barycenter of the emission bands with the variation of the excitation wavelength is partially due to the cutoff caused by the filters used to eliminate the excitation signal from the emission spectrum. However, the shift may indicate either that the activator center is occupying multiple sites with different crystal field strengths in the host lattice, or the presence of defects in the structure of the X-Hec materials. The multisite origin for emission is also witnessed in the decrease of emission band width [42] with increasing excitation wavelength.
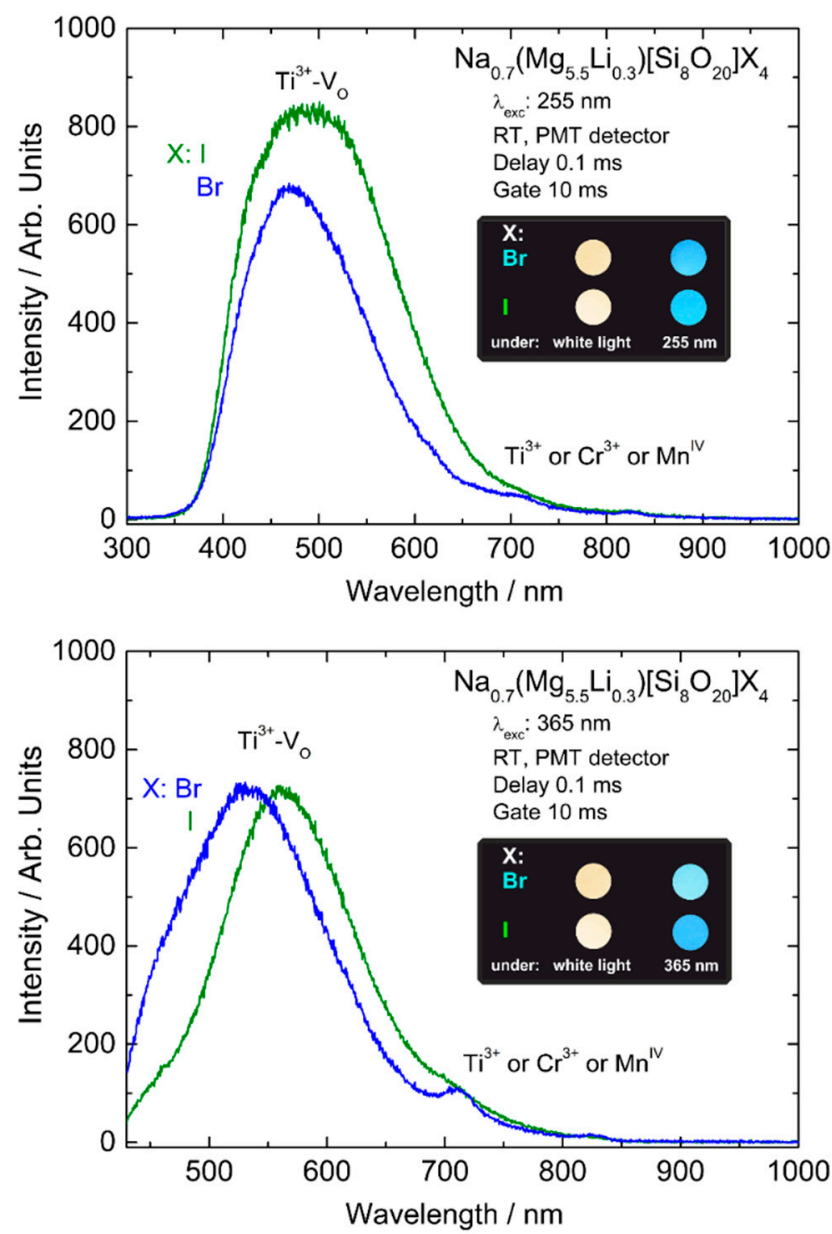

Figure 7. The emission spectra of the bromohectorite and iodohectorite under $255 \mathrm{~nm}$ (top) and $365 \mathrm{~nm}$ (bottom) excitation. The inserted photos illustrate the visual aspect of the materials under white light and when irradiated with $255 \mathrm{~nm}$ or $365 \mathrm{~nm}$. 
Similar blue-green emission has previously been observed for other silicates such as fluorohectorite [23], chlorohectorite [24], montmorillonite [43], kaolinite [44], pyrophyllite [45], topaz $\left(\mathrm{Al}_{2} \mathrm{SiO}_{4}(\mathrm{~F}, \mathrm{OH})_{2}\right)$ [46], synthetic hackmanite $\left(\mathrm{Na}_{8} \mathrm{Al}_{6} \mathrm{Si}_{6} \mathrm{O}_{24}(\mathrm{Cl}, \mathrm{S})_{2}\right)$ [47,48], benitoite $\left(\mathrm{BaTiSi}_{3} \mathrm{O}_{9}\right)$ [49], and $\mathrm{SiO}_{2}$ [50,51]. The literature presents mainly two different explanations for the origin of this blue-green emission. One proposition categorizes this emission as photoelectric response as well as inner center and recombination type of luminescence [52], attributing the blue emission to triplet-singlet transition in twofold coordinated Si centers [53], due to oxygen deficit and irradiation effects [50]. The second proposition associates the emission with luminescent centers containing trivalent titanium paired with an oxide vacancy, which may exist either as matrix element or as an impurity [23,24,46-49].

It was shown previously for synthetic chlorohectorite [24] that the intensity of the blue emission band increases if titanium is deliberately doped to the material. Therefore, the band was assigned to $\mathrm{Ti}^{3+}$. It has also been verified that although natural hectorite presents a similar blue emission often attributed to $\left[\mathrm{SiO}_{2}\right]^{2-}$ centers, it has different luminescence features than have been observed for halogen-hectorites [24]. Also, previous reports have shown that Ti species can occur as impurities in silicates, generating similar emission features as reported for silicate glasses [54], fluorohectorites [23] and chlorohectorites [24]. The materials studied in the current work have low contents of Ti, confirmed from their respective XRF spectra (Figure 2). It has been proposed previously that, in the case of synthetic halogen-hectorites, the titanium impurities originate from the $\mathrm{SiO}_{2}$ used as a precursor to prepare the materials, where $\mathrm{Si}^{\mathrm{IV}}$ has been replaced by $\mathrm{Ti}^{\mathrm{IV}}$. Since the octahedral coordination is the preferred geometry for titanium compounds, the initial impurities have been suggested to migrate to the octahedral layers substituting isomorphically either $\mathrm{Mg}^{2+}$ or $\mathrm{Li}^{+}$. The low reduction potential between $\mathrm{Ti}^{\mathrm{IV}}$ and $\mathrm{Ti}^{3+}$ allows the easy interconversion of these species; however, the trivalent form of titanium should be the majority species because it better matches the size and charge of the octahedral units $[23,24]$. It can thus be assumed that a titanium-related center is responsible for the blue emission in $\mathrm{Br}-\mathrm{Hec}$ and I-Hec. According to previous literature, this blue emission can be attributed to $\mathrm{TiO}_{6}$ entities as reported for Benitoite $\left(\mathrm{BaTiSi}_{3} \mathrm{O}_{9}\right)$ [43] or to $\mathrm{Ti}^{3+}-\mathrm{V}_{\mathrm{O}}$ (oxygen vacancy) pairs $[23,24,47,48]$. Moreover, the doping of the X-Hec materials with $\mathrm{Ti}^{3+}\left(\mathrm{x}_{\mathrm{Ti}}=0.1 \mathrm{~mol} \%\right)$ increases the intensity of the main emission (Figure A6), without significant changes to its band position confirming titanium as the luminescent center.

In addition to the blue emission band, there are also luminescence signals at ca. 720 and $830 \mathrm{~nm}$. As is known from the Ti:sapphire laser [22], $\mathrm{Ti}^{3+}$ can also emit in the red and NIR due to the ${ }^{2} \mathrm{E} \rightarrow{ }^{2} \mathrm{~T}_{2}$ transition. This is present as a wide band also in natural Benitoite [55]. For Br-Hec and I-Hec these red and NIR emissions are observed as bands or lines depending on the excitation wavelength (Figures 7 , $\mathrm{A} 4$ and $\mathrm{A5}$ ). The line-like shape suggests the presence of other emitters than $\mathrm{Ti}^{3+}$. Thus, impurity $3 \mathrm{~d}^{3}$ ions $\mathrm{Cr}^{3+}$ and $\mathrm{Mn}^{4+}$ which show the characteristic emission $\mathrm{R}$ lines $\left({ }^{2} \mathrm{E}^{2} \mathrm{~T}_{2} \rightarrow{ }^{4} \mathrm{~A}_{2}\right.$ transition) in the red-NIR range seem to be probable candidates. These ions also show emission bands in the same spectral range at appropriate crystal field strength [22]. The contents of $\mathrm{Mn}$ and $\mathrm{Cr}$ in the present materials were determined with ICP-MS to be around $4(\mathrm{Mn})$ and $0.5 \mathrm{ppm}(\mathrm{Cr})$. Therefore, both $\mathrm{Cr}^{3+}$ and $\mathrm{Mn}^{4+}$ can be considered as possible emitters along with $\mathrm{Ti}^{3+}$, as was previously reported for natural benitoite [55].

The main blue-green emission band has a red shift trend: the center of this blue emission has been identified at 460, 465, 470 and $490 \mathrm{~nm}$ for fluorohectorite [23], chlorohectorite [24], bromohectorite and iodohectorite, respectively. This observed emission red shift can be explained using the molecular orbital theory: the halides are $\pi$-donor ligands ( $\pi$-donor stengths: $\mathrm{F}^{-}<\mathrm{Cl}^{-}<\mathrm{Br}^{-}<\mathrm{I}^{-}$), which have full $\pi$ orbitals lower in energy than the $3 \mathrm{~d}^{1}$ orbitals of $\mathrm{Ti}^{3+}$. When they form molecular orbitals with the $t_{2 g}$ orbitals of $\mathrm{Ti}^{3+}$, the hitherto nonbonding $\mathrm{Ti}^{3+} \mathrm{t}_{2 \mathrm{~g}}$ orbitals split into bonding and antibonding MOs. The energy is increased, bringing them closer in energy to the antibonding e $e_{g}$ orbitals [56]. The energy difference between the antibonding $t_{2 g}$ and $e_{g}$ MOs may be considered as the ligand field splitting responsible for the transition in visible. The higher is the $\pi$-donor strength, the lower is the energy difference between $t_{2 g}$ and $e_{g}$ generating the noticed red shift. Similar observations have been 
reported, for example, in perovskites showing the red shift when bromine was replaced by iodine in the inorganic octahedral $\mathrm{PbX}_{6}(\mathrm{X}=\mathrm{Br}$ or I) [57].

The excitation spectra of the bromohectorite and iodohectorite (Figure 8) confirm the role of $\mathrm{Ti}^{3+}$ as an activator center in these materials. The broad bands observed at ca. 400 and $410 \mathrm{~nm}$ for $\mathrm{Br}-\mathrm{Hec}$ and $\mathrm{I}-\mathrm{Hec}$, respectively, are assigned to electronic transitions from the $t_{2 \mathrm{~g}}$ to $\mathrm{e}_{\mathrm{g}}$ energy levels of $\mathrm{Ti}^{3+}$, which agrees with previous reports for $\mathrm{Ti}^{3+}$ in fluorohectorite $(380 \mathrm{~nm})$ [23], chlorohectorite $(370 \mathrm{~nm})$ [24] and monoclinic $\mathrm{ZrO}_{2}(314 \mathrm{~nm})$ [58], considering that $\mathrm{d}-\mathrm{d}$ transitions are sensitive to the crystal field strength. The wide bands at ca. $300 \mathrm{~nm}$ are related to the $\mathrm{e}^{-}\left(\mathrm{O}^{2-}(2 \mathrm{p})\right) \rightarrow \mathrm{Ti}^{\mathrm{IV}}$ charge transfer, which can occur through two possible molecular transitions: $\mathrm{t}_{1 \mathrm{u}}\left(\pi^{\mathrm{b}}\right) \rightarrow \mathrm{t}_{2 \mathrm{~g}}\left(\pi^{*}\right)$ or $\mathrm{t}_{2 \mathrm{u}}(\pi) \rightarrow \mathrm{t}_{2 \mathrm{~g}}\left(\pi^{*}\right)$, being typically observed at ca. $280 \mathrm{~nm}[23,24,42,48,59]$. Lastly, the energy gaps between the valence and the conduction bands are identified at ca. $256 \mathrm{~nm}(4.84 \mathrm{eV})$ and $248 \mathrm{~nm}(5.00 \mathrm{eV})$ for Br-Hec and I-Hec, respectively, which agree with the characteristic band gap energy $4.7 \mathrm{eV}(260 \mathrm{~nm})$ of hectorites [60]. Since the excitation spectra were recorded by monitoring the blue emission, the observation of the valence to conduction band transition confirms that titanium is in the hectorite structure and not present as an isolated impurity phase.

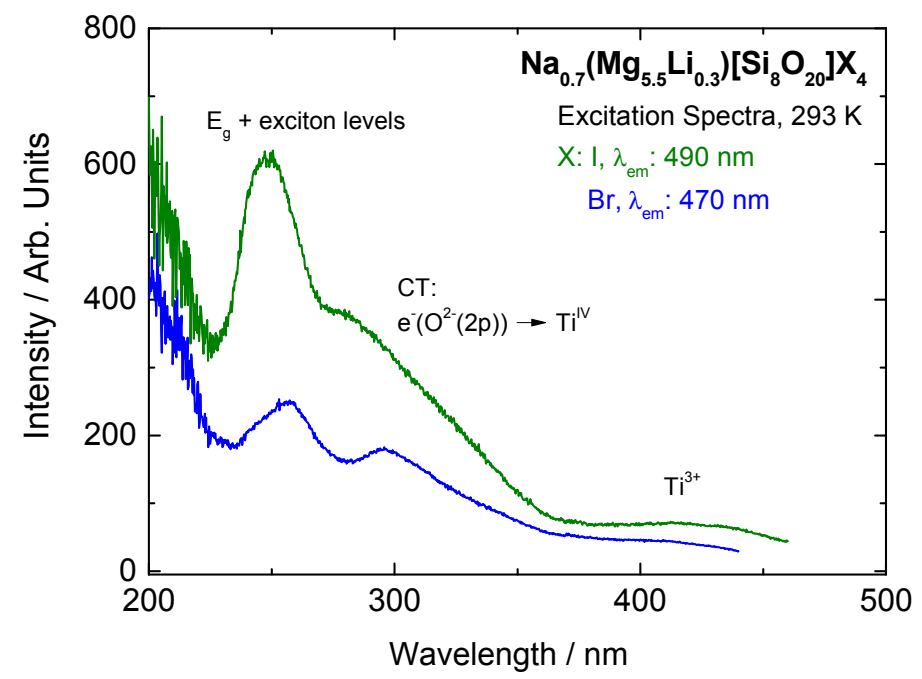

Figure 8. The excitation spectra of the bromohectorite $\left(\lambda_{\mathrm{em}}: 470 \mathrm{~nm}\right)$ and iodohectorite $\left(\lambda_{\mathrm{em}}: 490 \mathrm{~nm}\right)$.

When the excitation spectra are recorded at different emission wavelengths (Figures A7 and A8), these three bands remain mainly in the same spectral position, which proves that the same activator center $\left(\mathrm{Ti}^{3+}\right)$ is responsible for the observed blue-green emission. When the excitation spectrum of $\mathrm{Br}-\mathrm{Hec}$ is recorded at $710 \mathrm{~nm}$ emission (Figure A7), it shows two bands at ca. 400 and $577 \mathrm{~nm}$. In minerals, the ${ }^{4} \mathrm{~A}_{2} \rightarrow{ }^{4} \mathrm{~T}_{1}$ and ${ }^{4} \mathrm{~A}_{2} \rightarrow{ }^{4} \mathrm{~T}_{2}$ transitions that excite the red/NIR emission are commonly observed at 410 and $550 \mathrm{~nm}$ for $\mathrm{Cr}^{3+}$ as well as 420 and $530 \mathrm{~nm}$ for $\mathrm{Mn}^{4+}$ [46]. This confirms that one or both of these ions is the origin of this line emission at $710 \mathrm{~nm}$.

The luminescence decay curves of Br-Hec and I-Hec (Figure 9) indicated that the materials present a short persistent luminescence, with a duration of ca. $5 \mathrm{~s}$, at room temperature. Both materials have at least three lifetimes obtained from a multiexponential fitting function. However, even with three components, only a part of each decay curve could be fitted reasonably. This indicates that several contributing processes are involved in the overall decay. It has been reported that $\mathrm{Ti}^{3+}$-doped materials have a typical emission lifetime lasting microseconds [61], but halogen-hectorites have shown much longer lifetimes, on the order of hundreds of milliseconds to seconds [23,24], which agrees with the lifetimes obtained from the fits to the decay curves of Br-Hec and I-Hec in this work (Table 1). This short persistent luminescence is explained through the existence of defects in the layered structure of these materials acting as shallow electron traps for short-time energy storage. Even though the bromo- and 
iodohectorites can store optical energy, they possess shallow traps that do not allow for any significant persistent luminescence at room temperature.

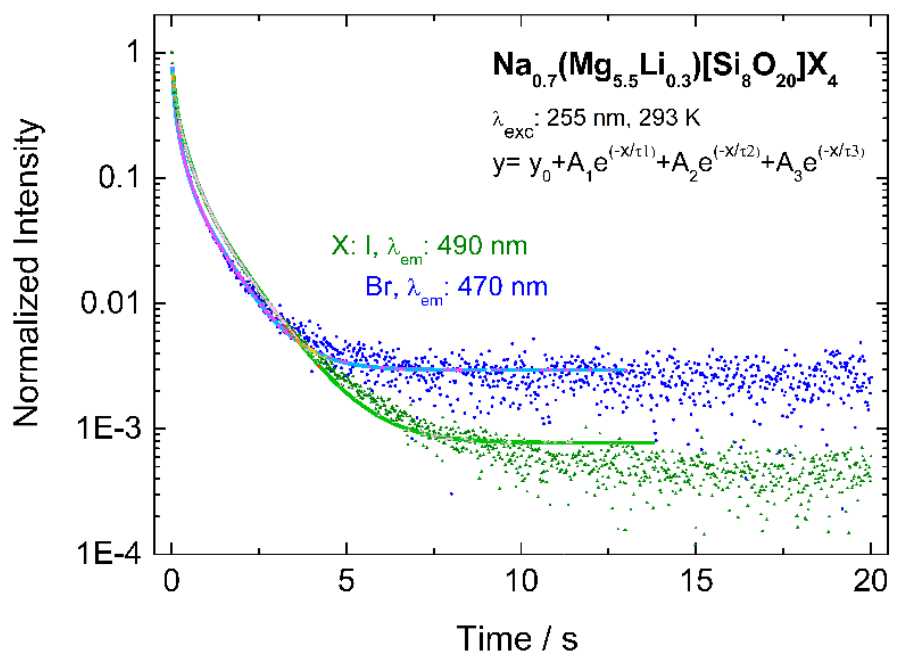

Figure 9. The luminescence decay $\left(\lambda_{\mathrm{exc}}: 255 \mathrm{~nm}\right)$ of bromohectorite $\left(\lambda_{\mathrm{em}}: 470 \mathrm{~nm}\right)$ and iodohectorite $\left(\lambda_{\mathrm{em}}: 490 \mathrm{~nm}\right)$.

Table 1. Emission lifetimes calculated for bromohectorite and iodohectorite by fitting the luminescence intensity (I) to the function: $I=I_{0}+A_{1} e^{-t / \tau 1}+A_{2} e^{-t / \tau 2}+A_{3} e^{-t / \tau 3}$. Here, $\mathrm{A}=$ amplitude, $\mathrm{t}=$ time and $\tau=$ lifetime. The values in parentheses show the SD (standard deviation) calculated.

\begin{tabular}{ccccccc}
\hline Parameters & $\boldsymbol{\tau}_{\mathbf{1}} / \mathbf{s}$ & $\mathbf{A}_{\mathbf{1}} / \%$ & $\boldsymbol{\tau}_{\mathbf{2}} / \mathbf{s}$ & $\mathbf{A}_{\mathbf{2}} / \%$ & $\boldsymbol{\tau}_{3} / \mathbf{s}$ & $\mathbf{A}_{\mathbf{3}} / \%$ \\
\hline Bromohectorite & $0.04(6)$ & 61 & $0.20(4)$ & 29 & $0.87(11)$ & 10 \\
Iodohectorite & $0.06(6)$ & 53 & $0.30(3)$ & 35 & $1.07(8)$ & 12 \\
\hline
\end{tabular}

\section{Discussion}

Br-Hec and I-Hec have been successfully synthesized and, to the best of the authors' knowledge, their structural and spectroscopic features are here reported for the first time. They present the same hexagonal crystal structure as nanocrystalline fluorohectorite without impurity phases detectable with XPD. Both materials' crystallites are approximately $3 \mathrm{~nm}$ along the 001 direction and have a d $\mathrm{d}_{001}$ spacing of $14.30 \AA$, which is suitable for intercalation of two monolayers of water in their interlayers at room temperature. The XRF spectra confirmed the chemical composition expected for the materials, showing the signals related to the $\mathrm{Mg} \mathrm{K}_{\alpha 1}$ and $\mathrm{Si} \mathrm{K} \mathrm{K}_{\alpha 1}$ emissions for both and the respective halogen emission of $B r L_{\alpha 1,2}$ or I $L_{\alpha 1}, I L_{\beta 1}$ and I $L_{\beta 2}$. Additionally, the spectra of both materials indicate the presence of $\mathrm{Ti}$ as an impurity, seen mainly through the weak line of its related $\mathrm{K}_{\beta 1}$ emission at $4.9 \mathrm{keV}$.

The FTIR spectra of $\mathrm{Br}-\mathrm{Hec}$ and I-Hec indicate the total replacement of the hydroxyl groups of hectorite by the respective halides, since bands related to the vibrations of hydroxyl groups in the octahedral layers of clay minerals were not observed. The ${ }^{29} \mathrm{Si}$ NMR spectra of both materials show the same chemical environment predicted for the silicon tetrahedral layers of synthetic hectorite, giving the $\mathrm{Q}^{3}$ (ca. $\left.-97 \mathrm{ppm}\right)$ and $\mathrm{Q}^{2}(-87)$ signals of $\mathrm{Si}(\mathrm{OMg})(\mathrm{OSi})_{3}$ and $\mathrm{Si}(\mathrm{OMg})(\mathrm{OSi})_{2} \mathrm{X}\left(\mathrm{X}=\mathrm{Br}^{-}\right.$or $\left.\mathrm{I}^{-}\right)$sites, respectively. The $\mathrm{Q}^{2} / \mathrm{Q}^{3}$ ratio indicates a higher degree of branching for the polymeric sheets of the $\mathrm{I}-\mathrm{Hec}(0.41)$ than for the $\mathrm{Br}-\mathrm{Hec}(0.37)$ materials.

The nitrogen sorption isotherms of Br-Hec and I-Hec indicated that both are mesoporous materials with plate-like packing. Br-Hec has a surface area of $385 \mathrm{~m}^{2} \mathrm{~g}^{-1}$, while I-Hec shows an area of $363 \mathrm{~m}^{2}$ $\mathrm{g}^{-1}$, considering the model of a multilayer coverage. The materials have a mesopore volume of ca. $0.50 \mathrm{~cm}^{3} \mathrm{~g}^{-1}$, constant for the adsorption and desorption curves, suggesting a potential feature for catalyst application. Both materials show thermal stability up to $800^{\circ} \mathrm{C}$. 
$\mathrm{Br}-\mathrm{Hec}$ and I-Hec have blue-green emission under UV radiation. The luminescence features are attributed to a $\mathrm{Ti}^{3+}$ impurity acting as the luminescent center in these materials. When irradiated at $255 \mathrm{~nm}, \mathrm{Br}-\mathrm{Hec}$ has this main emission band at $470 \mathrm{~nm}$, while observed at $490 \mathrm{~nm}$ for the I-Hec. This red shift was explained using the MO theory to occur due to the differing $\pi$-donor strengths of the halogens. The center of the main emission band varies with the excitation wavelength, indicating that the activator center is occupying multiple sites in the host lattice, which was also observed from the emission band widths. The excitation spectra of Br-Hec and I-Hec confirm $\mathrm{Ti}^{3+}$ as the activator center in these materials, showing the bands related to electronic transitions from the $t_{2 g}$ to $e_{g}$ energy levels of $\mathrm{Ti}^{3+}(\mathrm{ca} .400 \mathrm{~nm}), \mathrm{e}^{-}\left(\mathrm{O}^{2-}(2 \mathrm{p})\right) \rightarrow \mathrm{Ti}^{\mathrm{IV}}$ charge transfer $(\mathrm{ca} .300 \mathrm{~nm})$, and the band gap energy (ca. $250 \mathrm{~nm}$ ). Both materials have persistent luminescence on the order of $5 \mathrm{~s}$, indicating the existence of electron traps that can store excitation energy for short periods of time only.

\section{Conclusions}

The synthesis and properties of the Br-Hec and I-Hec materials have been presented for the first time in the current work. The materials adopt the same crystal structure and chemical environment as hectorite clays. However, replacement with halogen ions gives these materials broader possibilities for application in the production of luminescent materials, thus making them potential candidates for a wide range of follow-up research. The X-Hec materials are candidates for generating luminescent materials by doping with rare earth ions. These materials could be used in the quantitative determination of bio-molecules, and bio-imaging in vitro, due to the high bio-compatibility of clay minerals. Also, up-convertor materials may be obtained through the co-doping of X-Hec materials with rare earth ions, e.g., $\mathrm{Er}^{3+}-\mathrm{Tm}^{3+}-\mathrm{Yb}^{3+}, \mathrm{Yb}^{3+}-\mathrm{Tm}^{3+}, \mathrm{Tm}^{3+}-\mathrm{Er}^{3+}$, etc. Such materials could be used as light-converting elements, enhancing the efficiency of commercially available solar cell devices.

The high specific surface area found in both materials could enable their further application in gas sensors or in electrochemical devices for charge storage. Br-Hec and I-Hec materials could also be used as heterogeneous catalysts in polymeric reactions: since they possess moderated thermal stability, easy structural modification, and nanosize along the 001 direction, they could generate a functionalized modifier of polymeric structures, thus enhancing the physical properties of the final product. Moreover, the production of the $\mathrm{p}-\mathrm{n}$ type of solar cells having X-Hec materials as the n-type element can be studied because of the X-Hec materials' abundance in negative free-carriers in their negative layers.

Acknowledgments: H.S.S. and J.H. acknowledge the Brazilian funding agency CNPq for the Ciência sem Fronteiras scholarships and the UTUGS for further funding. H.S.S. and J.M.C. acknowledge the Academy of Finland-CNPq Finland-Brazil bilateral project (\#490242/2012-0). H.S.S. also acknowledges Lucas C. V. Rodrigues of the Universidade de São Paulo-SP-Brazil for his collaboration on the application and extension of the research grant.

Author Contributions: H.S.S. conceived, designed and performed most of the experiments, analyzed the data and wrote the paper; I.N. and J.S. performed the ${ }^{29}$ Si MAS NMR measurements and revised the interpretation of the data; T.L. helped with the interpretation of the data and revised the manuscript; E.M. measured the nitrogen sorption isotherms and revised the interpretation of the data; J.M.C. assisted in the interpretation of the titanium luminescence and revised the manuscript; P.D. helped with the FTIR measurements and revised the interpretation of the data; H.F.B. contributed on the revision of the manuscript; J.H. contributed on the elaboration of the project, interpretation of the data, and revision of the manuscript; M.L. supervised the research project, elaborated the experiments, provided the materials and apparatus needed, and co-wrote and revised the manuscript.

Conflicts of Interest: The authors declare no conflict of interest. 


\section{Appendix}

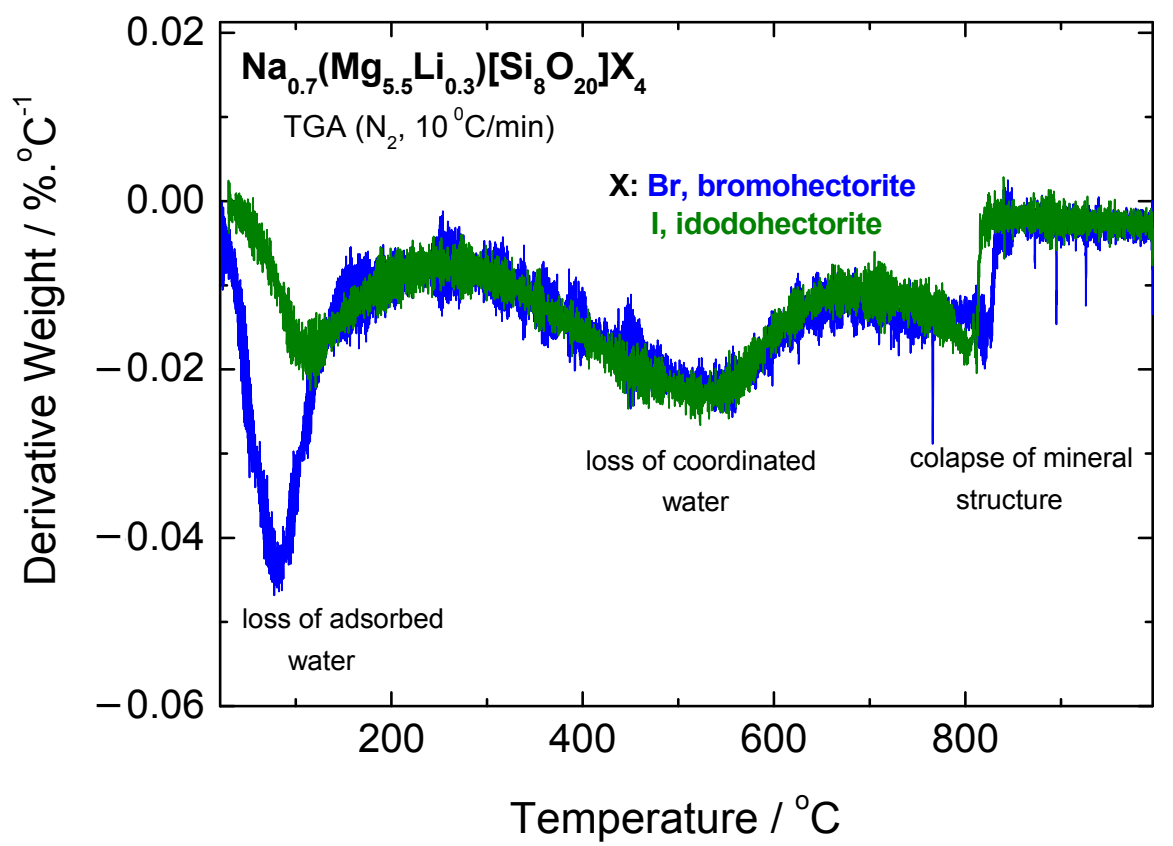

Figure A1. The first derivative of the TGA curves of bromohectorite and iodohectorite.

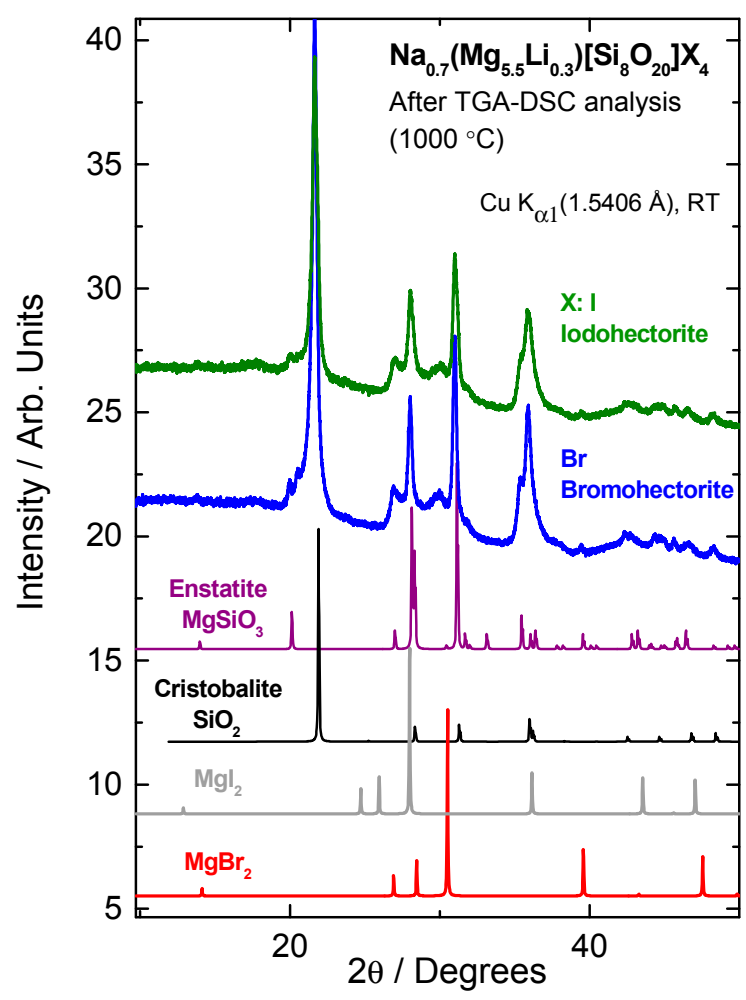

Figure A2. The XPD measurements of bromohectorite and iodohectorite after heating to $1000{ }^{\circ} \mathrm{C}$. 

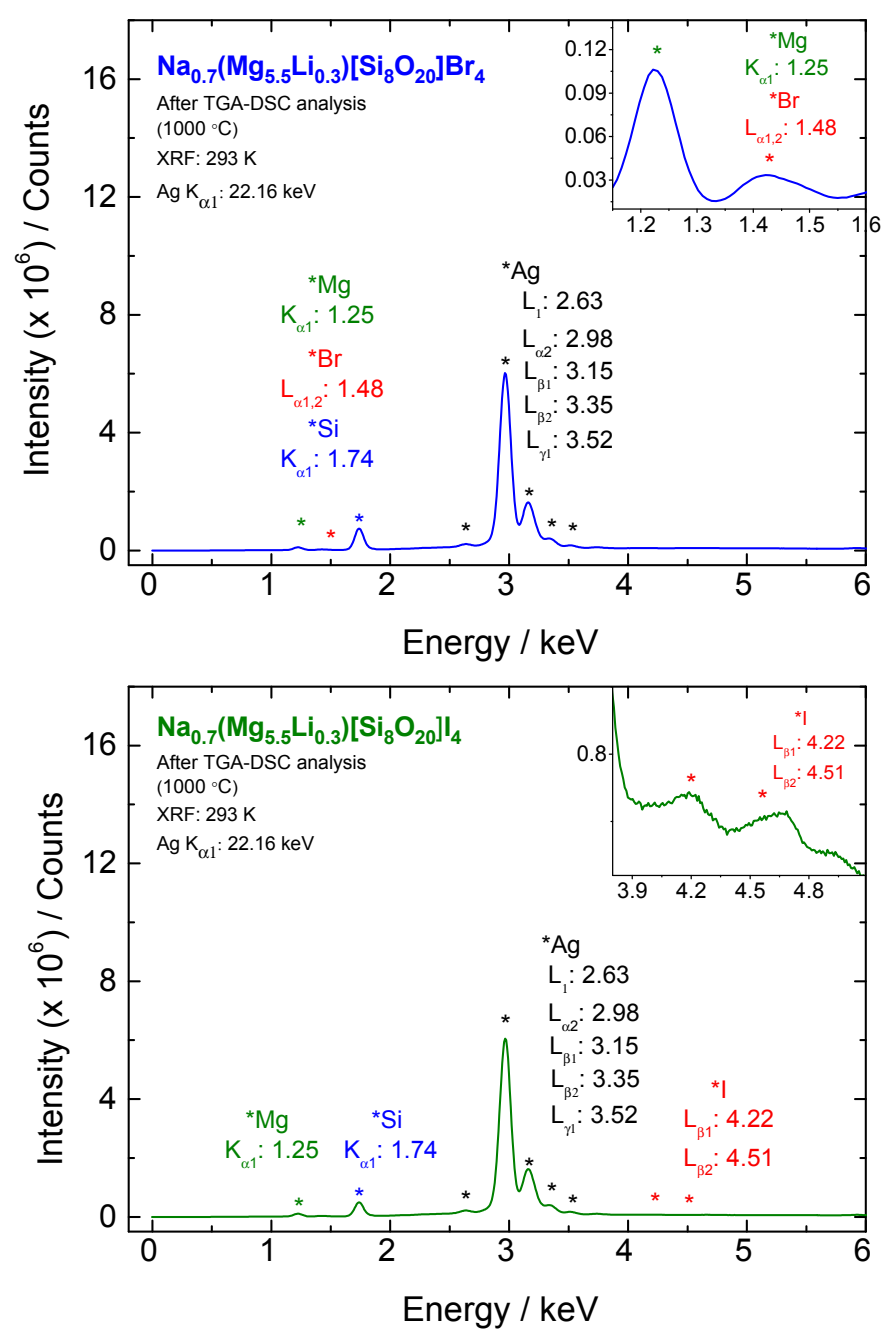

Figure A3. The XRF measurements of bromohectorite (top) and iodohectorite (bottom) after heating to $1000{ }^{\circ} \mathrm{C}$.

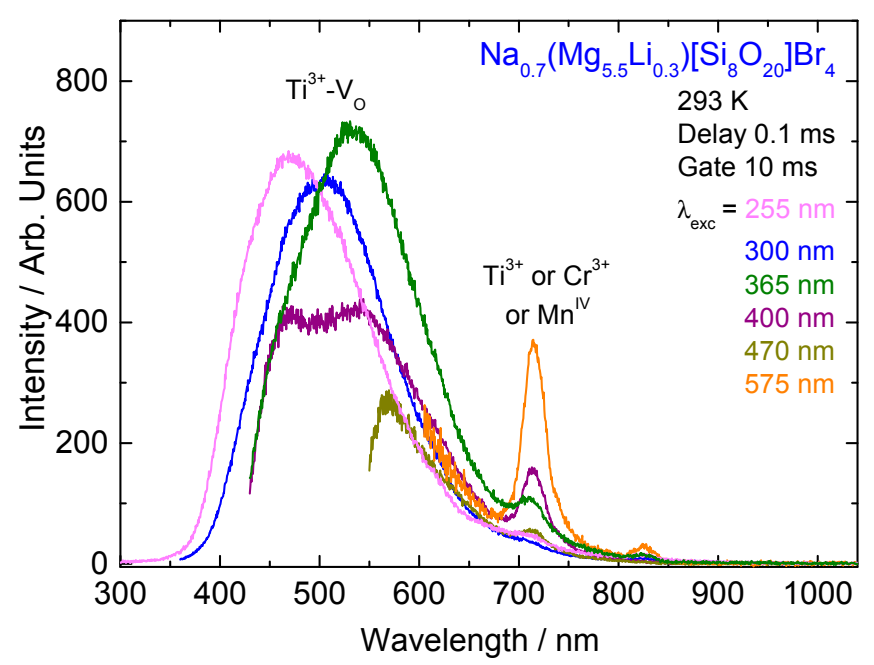

Figure A4. The emission spectra of bromohectorite recorded with several excitation wavelengths. The data are not corrected for the excitation source intensity at different wavelengths. 


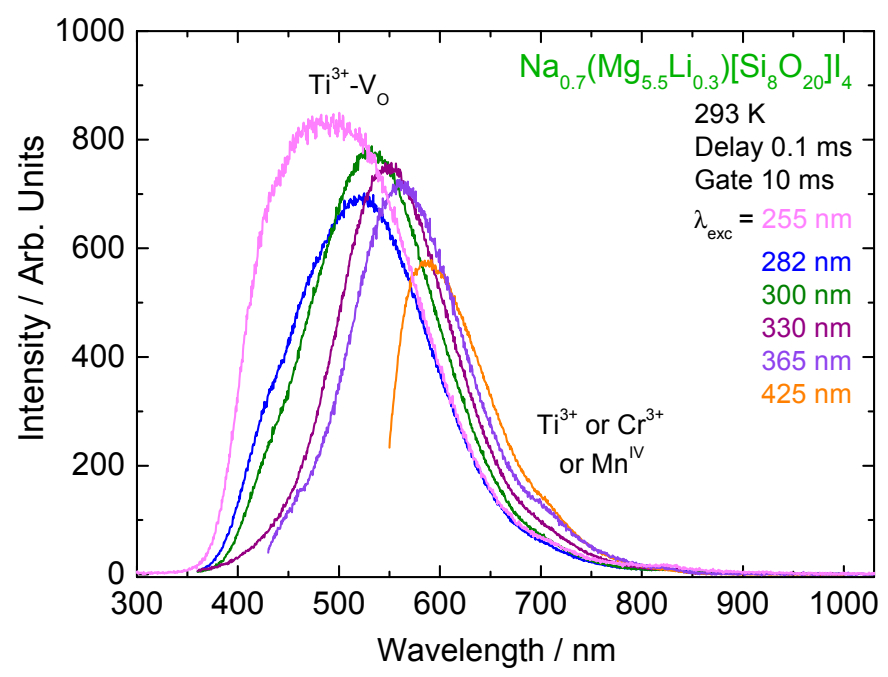

Figure A5. Emission spectra of iodohectorite recorded at several excitation wavelengths. The data are not corrected for the excitation source intensity at different wavelengths.
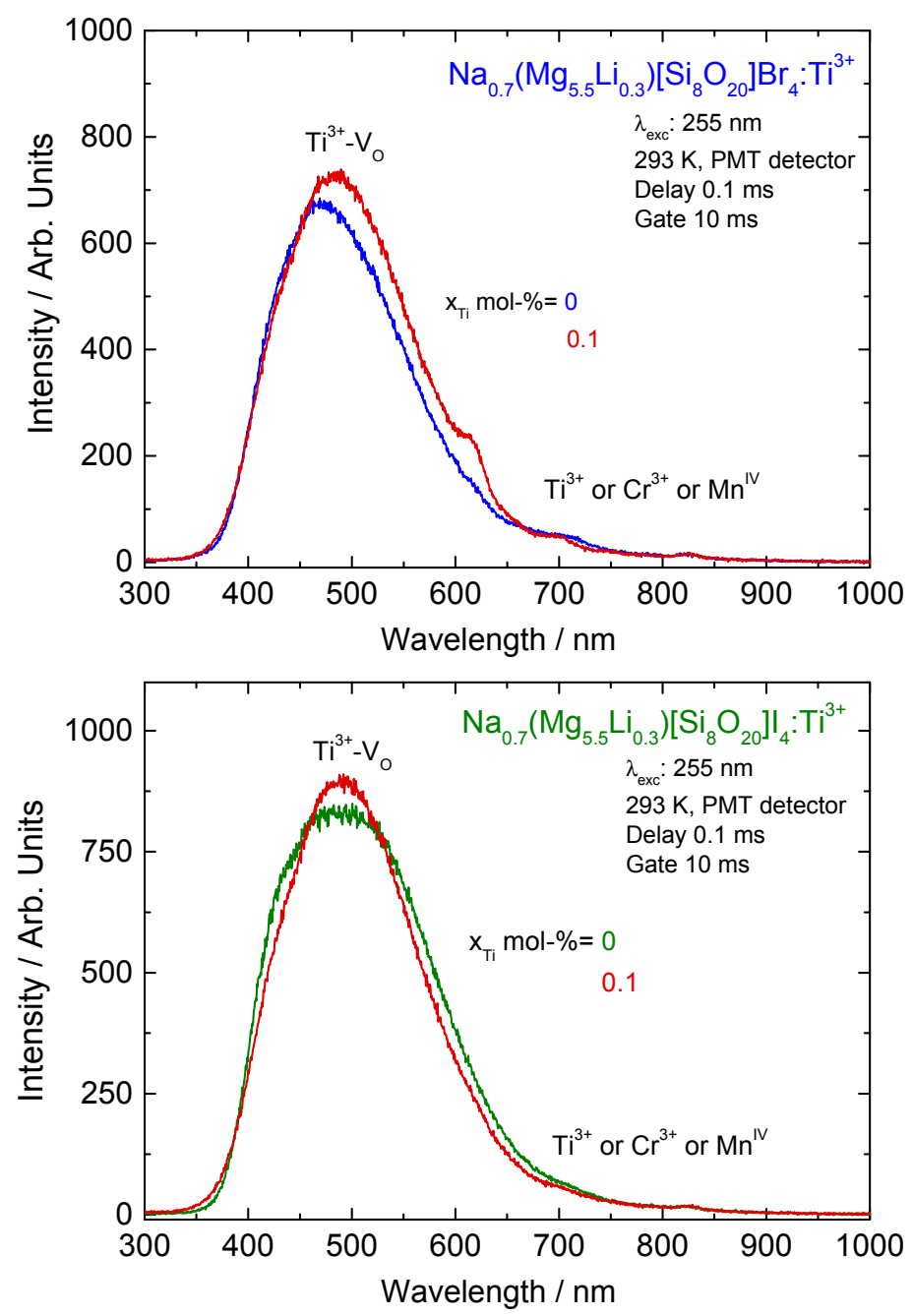

Figure A6. Emission spectra $\left(\lambda_{\text {exc }}: 255 \mathrm{~nm}\right.$ ) of Br-Hec:Ti ${ }^{3+}$ (top) and I-Hec:Ti ${ }^{3+}$ (bottom), $\mathrm{x}_{\mathrm{Ti}}=0.1 \mathrm{~mol} \%$. 


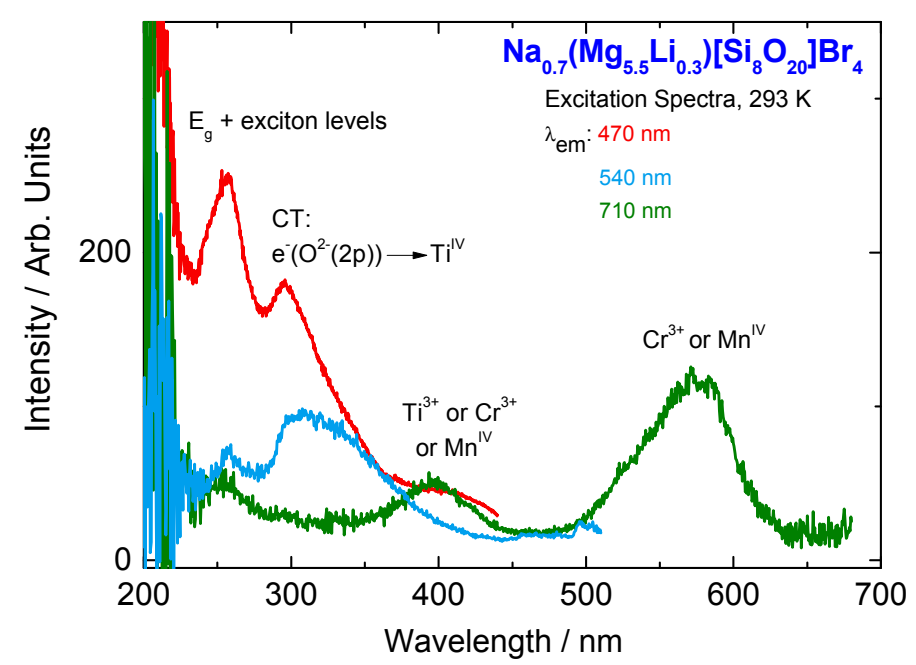

Figure A7. Excitation spectra of bromohectorite recorded at several emission wavelengths. The data are not corrected for the detector sensitivity at different emission wavelengths.

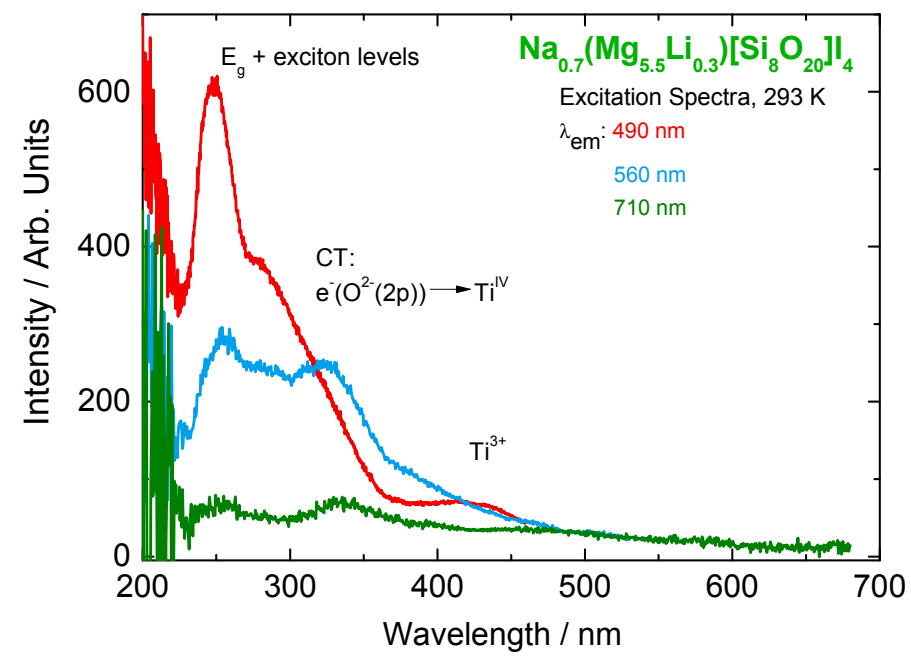

Figure A8. Excitation spectra of iodohectorite recorded at several emission wavelengths. The data are not corrected for the detector sensitivity at different emission wavelengths.

\section{References}

1. Tomás, H.; Alves, C.S.; Rodrigues, J. Laponite ${ }^{\circledR}$ : A key nanoplatform for biomedical applications? Nanomed. Nanotechnol. Biol. Med. 2017, in press. [CrossRef]

2. Bergaya, F.; Theng, B.K.G.; Legaly, G. Handbook of Clay Sciences, 1st ed.; Elsevier Ltd.: Amsterdam, The Netherlands; London, UK, 2006; ISBN 978-0-08-044183-2.

3. Li, W.; Dong, H.; Wang, L.; Li, N.; Guo, X.; Li, J.; Qiu, Y. Montmorillonite as bifunctional buffer layer material for hybrid perovskite solar cells with protection from corrosion and retarding recombination. J. Mater. Chem. A 2014, 2, 13587-13592. [CrossRef]

4. Wang, X.; Kulkarni, S.A.; Ito, B.I.; Batabyal, S.K.; Nonomura, K.; Wong, C.C.; Grätzel, M.; Mhaisalkar, S.G.; Uchida, S. Nanoclay Gelation Approach toward Improved Dye-Sensitized Solar Cell Efficiencies: An Investigation of Charge Transport and Shift in the $\mathrm{TiO}_{2}$ Conduction Band. ACS Appl. Mater. Interfaces 2013, 5, 444-450. [CrossRef] [PubMed]

5. Chen, L.; Chen, X.L.; Zhou, C.H.; Yang, H.M.; Ji, S.F.; Tong, D.S.; Zhong, Z.K.; Yu, W.H.; Chu, M.Q. Environmental-friendly montmorillonite-biochar composites: Facile production and tunable adsorption-release of ammonium and phosphate. J. Clean. Prod. 2017, 156, 648-659. [CrossRef] 
6. Zhang, G.; Gao, Y.; Zhang, Y.; Guo, Y. $\mathrm{Fe}_{2} \mathrm{O}_{3}$-Pillared Rectorite as an Efficient and Stable Fenton-Like Heterogeneous Catalyst for Photodegradation of Organic Contaminants. Environ. Sci. Technol. 2010, 44, 6384-6389. [CrossRef] [PubMed]

7. Kibanova, D.; Cervini-Silva, J.; Destaillats, H. Efficiency of Clay-TiO 2 Nanocomposites on the Photocatalytic Elimination of a Model Hydrophobic Air Pollutant. Environ. Sci. Technol. 2009, 43, 1500-1506. [CrossRef] [PubMed]

8. Micó-Vicent, B.; López, M.; Bello, A.; Martínez, N.; Martínez-Verdú, F. Optimum MultilayerGraphene-Montmorillonite Composites From Sugar for Thermosolar Coatings Formulations. J. Sol. Energy Eng. 2017, 139, 31005. [CrossRef]

9. Choudalakis, G.A.; Kalo, H.; Breu, J.; Gotsis, A.D. $\mathrm{CO}_{2}$ gas barrier properties in polymer nanocomposite coatings containing Li-hectorite clays. J. Appl. Polym. Sci. 2014, 131, 40805. [CrossRef]

10. López-Galindo, A.; Viseras, C.; Cerezo, P. Compositional, technical and safety specifications of clays to be used as pharmaceutical and cosmetic products. Appl. Clay Sci. 2007, 36, 51-63. [CrossRef]

11. Kloprogge, J.T.; Komarneni, S.; Amonette, J.E. Synthesis of smectite clay minerals: A critical review. Clays Clay Miner. 1999, 47, 529-554. [CrossRef]

12. Tully, J.; Yendluri, R.; Lvov, Y. Halloysite Clay Nanotubes for Enzyme Immobilization. Biomacromolecules 2016, 17, 615-621. [CrossRef] [PubMed]

13. Cavallaro, G.; Lazzara, G.; Milioto, S.; Parisi, F.; Sanzillo, V. Modified Halloysite Nanotubes: Nanoarchitectures for Enhancing the Capture of Oils from Vapor and Liquid Phases. ACS Appl. Mater. Interfaces 2014, 6, 606-612. [CrossRef] [PubMed]

14. Ruiz-Hitzky, E.; Aranda, P.; Darder, M.; Rytwo, G. Hybrid materials based on clays for environmental and biomedical applications. J. Mater. Chem. 2010, 20, 9306-9321. [CrossRef]

15. Petra, L.; Billik, P.; Melichová, Z.; Komadel, P. Mechanochemically activated saponite as materials for $\mathrm{Cu}^{2+}$ and $\mathrm{Ni}^{2+}$ removal from aqueous solutions. Appl. Clay Sci. 2017, 143, 22-28. [CrossRef]

16. Dos Santos, E.C.; Rozynek, Z.; Hansen, E.L.; Hartmann-Petersen, R.; Klitgaard, R.N.; Løbner-Olesen, A.; Michels, L.; Mikkelsen, A.; Plivelic, T.S.; Bordallo, H.N.; et al. Ciprofloxacin intercalated in fluorohectorite clay: Identical pure drug activity and toxicity with higher adsorption and controlled release rate. RSC Adv. 2017, 7, 26537-26545. [CrossRef]

17. Madhup, M.K.; Shah, N.K.; Parekh, N.R. Investigation and improvement of abrasion resistance, water vapor barrier and anticorrosion properties of mixed clay epoxy nanocomposite coating. Prog. Org. Coat. 2017, 102, 186-193. [CrossRef]

18. Ryu, S.-J.; Kim, A.; Kim, M.D.; Hong, S.W.; Min, S.S.; Lee, J.-H.; Lee, J.-K.; Jung, H. Photoluminescent europium(III) complex intercalated in natural and synthetic clay minerals for enhanced latent fingerprint detection. Appl. Clay Sci. 2014, 101, 52-59. [CrossRef]

19. Tchoubar, C. Clay minerals: Their structure, behaviour and use-X-ray studies of defects in clays. Philos. Trans. R. Soc. Lond. Ser. A Math. Phys. Eng. Sci. 1984, 311, 259-269. [CrossRef]

20. Carrado, K.A. Preparation of hectorite clays utilizing organic and organometallic complexes during hydrothermal crystallization. Ind. Eng. Chem. Res. 1992, 31, 1654-1659. [CrossRef]

21. Ziadeh, M.; Chwalka, B.; Kalo, H.; Schütz, M.R.; Breu, J. A simple approach for producing high aspect ratio fluorohectorite nanoplatelets utilizing a stirred media mill (ball mill). Clay Miner. 2012, 47, 341-353. [CrossRef]

22. Blasse, G.; Grabmaier, B.C. Luminescent Materials, 1st ed.; Springer: Berlin, Germany, 1994; ISBN 978-3-642-79017-1.

23. Santos, H.S.; Lastusaari, M.; Laihinen, T.; Viinikanoja, A.; Brito, H.F.; Rodrigues, L.C.V.; Swart, H.C.; Hölsä, J. Persistent Luminescent Non-Doped Layered Nanosilicate. Mater. Today Proc. 2016, 3, 2822-2830. [CrossRef]

24. Santos, H.S.; Carvalho, J.M.; Viinikanoja, A.; Hyppänen, I.; Laihinen, T.; Romani, E.C.; Larrudé, D.G.; Tuominen, M.; Laukkanen, P.; Swart, H.C.; et al. Glowing synthetic chlorohectorite: The luminescent features of a trioctahedral clay mineral. J. Lumin. 2017, 192, 567-573. [CrossRef]

25. Scherrer, P. Bestimmung der Grösse und der inneren Struktur von Kolloidteilchen mittels Röntgensrahlen. Math. Phys. Klasse 1918, 1918, 98-100.

26. Brunauer, S.; Emmett, P.H.; Teller, E. Adsorption of gases in multimolecular layers. J. Am. Chem. Soc. 1938, 60, 309-319. [CrossRef] 
27. Rouquerol, J.; Avnir, D.; Fairbridge, C.W.; Everett, D.H.; Haynes, J.M.; Pernicone, N.; Ramsay, J.D.F.; Sing, K.S.W.; Unger, K.K. Recommendations for the characterization of porous solids (Technical Report). Pure Appl. Chem. 1994, 66, 1739-1758. [CrossRef]

28. Reddy, U.V.; Bowers, G.M.; Loganathan, N.; Bowden, M.; Yazaydin, A.O.; Kirkpatrick, R.J. Water Structure and Dynamics in Smectites: X-ray Diffraction and ${ }^{2} \mathrm{H}$ NMR Spectroscopy of Mg-, Ca-, Sr-, Na-, Cs-, and Pb-Hectorite. J. Phys. Chem. C 2016, 120, 8863-8876. [CrossRef]

29. Auerbach, S.M.; Carrado, K.A.; Dutta, P.K. Handbook of Layered Materials, 1st ed.; Marcel Dekker: New York, NY, USA, 2004; ISBN 9780824753498.

30. Kalo, H.; Milius, W.; Breu, J. Single crystal structure refinement of one- and two-layer hydrates of sodium fluorohectorite. RSC Adv. 2012, 2, 8452-8459. [CrossRef]

31. Thompson, A.C.; Kirz, J.; Attwood, D.T.; Gullikson, E.M.; Howells, M.R.; Kortright, J.B.; Liu, Y.; Robinson, A.L.; Underwood, J.H.; Kim, K.H.; et al. X-ray Data Booklet, 3rd ed.; Thompson, A.C., Ed.; Lawrence Berkeley National Laboratory: Berkeley, CA, USA, 2009. Available online: http:/ /xdb.lbl.gov/ (accessed on 8 October 2017).

32. Farmer, V.C. Differing effects of particle size and shape in the infrared and Raman spectra of kaolinite. Clay Miner. 1998, 33, 601-604. [CrossRef]

33. Vicente, I.; Salagre, P.; Cesteros, Y. Preparation of pure hectorite using microwaves. Phys. Procedia 2010, 8 , 88-93. [CrossRef]

34. Jaynes, W.F.; Traina, S.J.; Bigham, J.M.; Johnston, C.T. Preparation and Characterization of Reduced-Charge Hectorites. Clays Clay Miner. 1992, 40, 397-404. [CrossRef]

35. Pálková, H.; Madejová, J.; Zimowska, M.; Bielańska, E.; Olejniczak, Z.; Lityńska-Dobrzyńska, L.; Serwicka, E.M. Laponite-derived porous clay heterostructures: I. Synthesis and physicochemical characterization. Microporous Mesoporous Mater. 2010, 127, 228-236. [CrossRef]

36. Gerstmans, A.; Urbanczyk, L.; Jèrôme, R.; Robert, J.L.; Grandjean, J. XRD and NMR characterization of synthetic hectorites and the corresponding surfactant-exchanged clays. Clay Miner. 2008, 43, $205-212$. [CrossRef]

37. Peyvandi, A.; Harsini, I.; Holmes, D.; Balachandra, A.M.; Soroushian, P. Characterization of ASR in concrete by ${ }^{29}$ Si MAS NMR spectroscopy. J. Mater. Civ. Eng. 2016, 28, 4015096. [CrossRef]

38. Alothman, Z.A. A Review: Fundamental Aspects of Silicate Mesoporous Materials. Materials 2012, 5, 2874-2902. [CrossRef]

39. Dogan, M.; Umran Dogan, A.; Irem Yesilyurt, F.; Alaygut, D.; Buckner, I.; Wurster, D.E. Baseline studies of the Clay Minerals Society Special Clays: Specific surface area by the Brunauer Emmett Teller (BET) method. Clays Clay Miner. 2007, 55, 534-541. [CrossRef]

40. Bergaya, F. The meaning of surface area and porosity measurements of clays and pillared clays. J. Porous Mater. 1995, 2, 91-96. [CrossRef]

41. Al-Mukhtar, M.; Qi, Y.; Alcover, J.F.; Conard, J.; Bergaya, F. Hydromechanical effects: (II) on the waterNa-smectite system. Clay Miner. 2000, 35, 537-544. [CrossRef]

42. Andrade, L.H.C.; Lima, S.M.; Novatski, A.; Neto, A.M.; Bento, A.C.; Baesso, M.L.; Gandra, F.C.G.; Guyot, Y.; Boulon, G. Spectroscopic assignments of $\mathrm{Ti}^{3+}$ and $\mathrm{Ti}^{4+}$ in titanium-doped $\mathrm{OH}^{-}$free low-silica calcium aluminosilicate glass and role of structural defects on the observed long lifetime and high fluorescence of $\mathrm{Ti}^{3+}$ ions. Phys. Rev. B 2008, 78, 224202-224211. [CrossRef]

43. Bezrodna, T.V.; Klishevich, G.V.; Melnyk, V.I.; Nesprava, V.V.; Puchkovska, G.A.; Chashechnikova, I.T. Photoluminescence of montmorillonite clay minerals modified by cetyltrimethylammonium bromide. J. Appl. Spectrosc. 2011, 77, 784-789. [CrossRef]

44. Garcia Guinea, J.; Correcher, V.; Valle-Fuentes, F.J. Thermoluminescence of Kaolinite. Radiat. Prot. Dosim. 1999, 84, 507-510. [CrossRef]

45. Götze, J.; Plötze, M.; Götte, T.; Neuser, R.D.; Richter, D.K. Cathodoluminescence (CL) and electron paramagnetic resonance (EPR) studies of clay minerals. Mineral. Petrol. 2002, 76, 195-212. [CrossRef]

46. Gaft, M.; Reisfeld, R.; Panczer, G. Modern Luminescence Spectroscopy of Minerals and Materials, 1st ed.; Springer: Berlin/Heidelberg, Germany, 2005; ISBN 978-3-540-26377-7.

47. Norrbo, I.; Gluchowski, P.; Hyppänen, I.; Laihinen, T.; Laukkanen, P.; Mäkelä, J.; Mamedov, F.; Santos, H.S.; Sinkkonen, J.; Tuomisto, M.; et al. Mechanisms of Tenebrescence and Persistent Luminescence in Synthetic Hackmanite $\mathrm{Na}_{8} \mathrm{Al}_{6} \mathrm{Si}_{6} \mathrm{O}_{24}(\mathrm{Cl}, \mathrm{S})_{2}$. ACS Appl. Mater. Interfaces 2016, 8, 11592-11602. [CrossRef] [PubMed] 
48. Norrbo, I.; Carvalho, J.M.; Laukkanen, P.; Mäkelä, J.; Mamedov, F.; Peurla, M.; Helminen, H.; Pihlasalo, S.; Härmä, H.; Sinkkonen, J.; et al. Lanthanide and Heavy Metal Free Long White Persistent Luminescence from Ti Doped Li-Hackmanite: A Versatile, Low-Cost Material. Adv. Funct. Mater. 2017, 27, 1606547. [CrossRef]

49. Gaft, M.; Nagli, L.; Waychunas, G.; Weiss, D. The nature of blue luminescence from natural benitoite $\mathrm{BaTiSi}_{3} \mathrm{O}_{9}$. Phys. Chem. Miner. 2004, 31, 365-373. [CrossRef]

50. Trukhin, A.N.; Goldberg, M.; Jansons, J.; Fitting, H.-J.; Tale, I.A. Silicon dioxide thin film luminescence in comparison with bulk silica. J. Non-Cryst. Solids 1998, 223, 114-122. [CrossRef]

51. Skuja, L.N.; Streletsky, A.N.; Pakovich, A.B. A new intrinsic defect in amorphous $\mathrm{SiO}_{2}$ : Twofold coordinated silicon. Solid State Commun. 1984, 50, 1069-1072. [CrossRef]

52. Trukhin, A.N.; Fitting, H.-J. Investigation of optical and radiation properties of oxygen deficient silica glasses. J. Non-Cryst. Solids 1999, 248, 49-64. [CrossRef]

53. Trukhin, A.N.; Skuja, L.N.; Boganov, A.G.; Rudenko, V.S. The correlation of the 7.6 eV optical absorption band in pure fused silicon dioxide with twofold-coordinated silicon. J. Non-Cryst. Solids 1992, 149, 96-101. [CrossRef]

54. Kumar, M.; Uniyal, A.; Chauhan, A.P.S.; Singh, S.P. Optical absorption and fluorescent behaviour of titanium ions in silicate glasses. Bull. Mater. Sci. 2003, 26, 335-341. [CrossRef]

55. Gaft, M.; Nagli, L.; Waychunas, G.; Panczer, G. The nature of red luminescence of natural benitoite $\mathrm{BaTiSi}_{3} \mathrm{O}_{9}$. Mineral. Petrol. 2005, 85, 33-44. [CrossRef]

56. Shriver, D.F.; Atkins, P.W. Inorganic Chemistry, 3rd ed.; Oxford University Press: Oxford, UK, 1999; ISBN 0198503318.

57. Yangui, A.; Pillet, S.; Lusson, A.; Bendeif, E.-E.; Triki, S.; Abid, Y.; Boukheddaden, K. Control of the white-light emission in the mixed two-dimensional hybrid perovskites $\left(\mathrm{C}_{6} \mathrm{H}_{11} \mathrm{NH}_{3}\right)_{2}\left[\mathrm{PbBr}_{4-\mathrm{x}} \mathrm{I}_{\mathrm{x}}\right]$. J. Alloys Compd. 2017, 699, 1122-1133. [CrossRef]

58. Carvalho, J.M.; Rodrigues, L.C.V.; Hölsä, J.; Lastusaari, M.; Nunes, L.A.O.; Felinto, M.C.F.C.; Malta, O.L.; Brito, H.F. Influence of titanium and lutetium on the persistent luminescence of $\mathrm{ZrO}_{2}$. Opt. Mater. Express 2012, 2, 331-340. [CrossRef]

59. Rogers, E.G.; Dorenbos, P. Vacuum energy referred $\mathrm{Ti}^{3+/ 4+}$ donor/acceptor states in insulating and semiconducting inorganic compounds. J. Lumin. 2014, 153, 40-45. [CrossRef]

60. Horwath, W.; Liang, Y.L. Variations of Chemical Composition and Band Gap Energies in Hectorite and Montmorillonite Clay Minerals on Sub-Micron Length Scales; Final Report: 2009008; Kearney Foundation of Soil Science: Davis, CA, USA, 2011.

61. Andrade, L.H.C.; Lima, S.M.; Novatski, A.; Udo, P.T.; Astrath, N.G.C.; Medina, A.N.; Bento, A.C.; Baesso, M.L.; Guyot, Y.; Boulon, G. Long Fluorescence Lifetime of $\mathrm{Ti}^{3+}$-Doped Low Silica Calcium Aluminosilicate Glass. Phys. Rev. Lett. 2008, 100, 027402. [CrossRef] [PubMed] 